\title{
IDENTIFICACIÓN Y ANÁLISIS COMPARATIVO DE LAS TENDENCIAS JURISPRUDENCIALES DE LA SUPERINTENDENCIA FINANCIERA DE COLOMBIA Y LA CORTE SUPREMA DE JUSTICIA RELATIVAS AL CONTRATO DE SEGURO ${ }^{1}$
}

\author{
IDENTIFICATION AND COMPARATIVE ANALYSIS \\ OF THE JURISPRUDENTIAL TENDENCIES OF THE \\ "SUPERINTENDENCIA FINANCIERA THE COLOMBIA" \\ AND THE SUPREME COURT OF JUSTICE \\ REGARDING THE INSURANCE CONTRACT
}

\author{
NATALIA ALEJANDRA DURÁN RONCANCIO', \\ JOAN SEBASTIÁN HERNÁNDEZ ORDOÑEZ, \\ DANILO ANDRÉS MUÑNOZ SALAS ${ }^{4}$, DAVID PARADA VARGAS', \\ STEFANIA RODRÍGUEZ PLAZAS, \\ DAVID AUGUSTO TEJEIRO CARRILLO ${ }^{7}$, MANUELA JIMÉNEZ VÉLEZ \\ Fecha de recepción: 22 de marzo de 2018 \\ Fecha de aceptación: 4 de abril de 2018 \\ Disponible en línea: 30 de junio de 2018
}

\section{Para Citar este articulo/To cite this article}

Durán Roncancio, Natalia Alejandra, Hernández Ordoñez, Joan Sebastián, Muñoz Salas, Danilo Andrés, Parada Vargas, David, Rodríguez Plazas, Stefania, Tejeiro Carrillo, David Augusto \& Jiménez Vélez, Manuela, Identificación y análisis comparativo de las tendencias jurisprudenciales de la superintendencia financiera de Colombia y la Corte Suprema de Justicia relativas al contrato de seguro, 48 Rev.Ibero-Latinoam.Seguros, 169-236 (2018). https://doi. org/10.11144/Javeriana.ris48.iact

doi:10.11144/Javeriana.ris48.iact

1 Trabajo de investigación, ganador en primer puesto, presentado en representación de la Pontificia Universidad Javeriana para participar en el concurso organizado por la Asociación Colombiana de Derecho de Seguros (ACOLDESE) denominado: Investigación sobre las decisiones judiciales en materia de contrato de seguro adoptadas por la Superintendencia Financiera de Colombia.

2 Abogada y especialista en derecho de seguros de la Pontificia Universidad Javeriana. Contacto: duranr.natalia@gmail.com

3 Abogado egresado de la Universidad Militar Nueva Granada, especialista en Derecho de Seguros de la Pontificia Universidad Javeriana y estudios de Derecho de Infraestructura de la Universidad de los Andes. Contacto: sebasyul2@gmail.com

4 Abogado egresado de la Universidad del Rosario, especialista en Derecho de Seguros de la Pontificia Universidad Javeriana. Contacto: munozsalasdanilo@gmail.com

5 Abogado egresado de la Pontificia Universidad Javeriana. Contacto: david.parada1590@hotmail.com

6 Abogada egresada de la universidad Externado de Colombia, especialista en derecho comercial y de seguros de la Pontificia Universidad Javeriana. Contacto: stefaniarodriguezp@hotmail.com

$7 \quad$ Abogado egresado de la Universidad del Rosario, especialista en Derecho de Seguros de la Pontificia Universidad Javeriana, magister en Argumentación Jurídica de la Universidad de Alicante en convenio con la Universidad de Palermo. Contacto: datc19@hotmail.com

8 Abogada egresada de la Pontificia Universidad Javeriana. Contacto: mjimenez@velezgutierrez.com 


\section{RESUMEN}

Transcurridos los primeros cinco años desde la creación de la Delegatura para Funciones Jurisdiccionales de la Superintendencia Financiera de Colombia, y dado que a la fecha esta entidad ha emitido más de 7533 providencias en ejercicio de las funciones judiciales que le fueron conferidas por el Artículo 57 de la Ley 1480 de 2011, consideramos pertinente efectuar un análisis descriptivo y crítico en torno a los pronunciamientos más destacados de la Delegatura en torno a las controversias más frecuentes en torno al Contrato de Seguro, en comparación con la línea jurisprudencial de la Sala Civil de la Corte Suprema de Justicia.

A través de este escrito ofrecemos a la comunidad académica un espacio de reflexión en torno a las perspectivas de protección al Consumidor de Seguros y la imperiosa necesidad de tutela de los intereses de quienes fungen como parte en la relación asegurativa, identificando así los puntos de convergencia y desencuentro.

Con tal fin, la presente investigación se ha delimitado en torno a las controversias asociadas a la nulidad relativa del contrato de seguro por declaraciones inexactas o reticentes a cargo de la parte asegurada, a la terminación 'automática' por impago de la prima, a las divergencias interpretativas, a la delimitación del riesgo mediante exclusiones y a conflictos derivados de la legitimación en la causa por activa de los herederos y cónyuge en el seno de los seguros de vida grupo deudores.

Palabras clave: Seguro; Seguro de vida; Grupo Deudores; Prescripción del contrato de seguro; competencia; casación; Superintendencia Financiera; Corte Suprema de Justicia; nulidad; reticencia; inexactitud en la declaración; declaración del estado del riesgo; delimitación del riesgo; interpretación del contrato de seguro; libertad probatoria; consumidor financiero; Riesgo inasegurable; vigencia del contrato de seguro; carga de la prueba; deber de información. 


\begin{abstract}
After the first five years since the creation of the Delegation for Jurisdictional Functions of the Financial Superintendence of Colombia, this entity has issued more than 7533 orders in the exercise of judicial functions that were conferred by Article 57 of Law 1480 of 2011, we consider it pertinent to carry out a descriptive and critical analysis of the most important pronouncements of the Superintendence regarding the most frequent controversies surrounding the Insurance Contract, in comparison with the jurisprudential line of the Civil Chamber of the Supreme Court of Justice.
\end{abstract}

Through this writing we offer the academic community a space for reflection on the perspectives of protection to the Insurance Consumer and the imperative need to protect the interests of those who act as part of the insurance relationship, thus identifying the points of convergence and disagreement.

To this end, the investigation has been delimited around the controversies associated with the relative nullity of the insurance contract due to inaccurate or reluctant statements by the insured party, the 'automatic' termination due to nonpayment of the premium, the interpretative divergences of the insurance contract, the delimitation of the risk by means of exclusions and the conflicts derived from the legitimation of the heirs and spouse in the Life Insurance for debtors.

Keywords: Insurance; Life insurance; Debtors Group; Prescription of the insurance contract; jurisdiction; cassation; Financial Superintendence; Supreme Court of Justice; nullity; reluctance; inaccuracy in the declaration; declaration of the state of the risk; delimitation of the risk; interpretation of the contract of insurance; free of proof; financial consumer; non insurable risk; validity of the insurance contract; burden of proof; duty of information.

\title{
SUMARIO
}

I. CONFLICTOS RELATIVOS A LA SUSCRIPCIÓN Y LA VIGENCIA DEL CONTRATO DE SEGURO. 1. Controversias en torno al régimen de anulabilidad del contrato de seguro por declaraciones inexactas y/o reticentes del tomador o asegurado. 1.1 Situaciones derivadas del conocimiento o desconocimiento del riesgo por parte del asegurador. 1.1.1. Obligatoriedad del tomador/asegurado de declarar el estado del riesgo frente a la no presentación de un cuestionario por parte del asegurador. 1.1.2 Alcance del conocimiento presuntivo del asegurador derivado de las inspecciones del riesgo. 1.1.2.1. Saneamiento de la reticencia o inexactitud derivado de la práctica de exámenes médicos. 1.2. Relevancia de las causas y motivos por los cuales un tomador/ asegurado incurre en reticencia o inexactitud, al momento de aplicar las sanciones derivadas de dicha conducta. 
1.3. La relación de causalidad entre la reticencia o inexactitud y el siniestro como elemento para dar lugar a las sanciones contempladas en el artículo 1058 del código de comercio. 1.4. Obligación a cargo del asegurador de verificar la información declarada por el tomador/asegurado. 1.5. Alcances del deber de información por parte del asegurador al tomador/asegurado respecto de la declaración del estado del riesgo. 1.6. Actos que comportan declaraciones inexactas y/o reticentes. 1.7. La carga de la prueba de la mala fe en casos de reticencia e inexactitud. 2. Controversias asociadas a la delimitación contractual de los riesgos asumidos por el asegurador. 2.1. De las exclusiones en el contrato de seguro. 2.2. De los riesgos inasegurables. 2.3. Conclusión. 3. Disyuntivas en torno a la interpretación del contrato de seguro. 3.1. Breve exposición de las construcciones jurisprudenciales referidas a la técnica de interpretación del contrato de seguro. 3.2. ¿Existe contradicción entre el método restrictivo y el método de contexto de interpretación de los contratos de seguro? 3.3. La incidencia de los criterios de interpretación en favor del consumidor contenidos en la Ley 1480 de 2011. 4. Análisis crítico y comparativo en torno a la terminación 'automática' del contrato de seguro por mora en el pago de la prima. 4.1. Sobre la terminación automática por mora y su diferencia con la revocación del contrato de seguro. 4.2. Divisibilidad de la póliza y sus certificados a efectos de la aplicación de la terminación por la mora en el pago de la prima. 4.3. El obligado al pago de la prima en seguros tomados por cuenta de un tercero. 4.4. El deber de informar sobre la terminación del contrato de seguro. 4.5. Conclusión. 5. Controversias asociadas al seguro de vida grupo deudores. 5.1. Legitimación en la causa de terceros que no son parte en el seguro de vida grupo deudores. 5.1.1. Casos analizados por la jurisprudencia. 5.1.2. Inexistencia de legitimación en la causa del codeudor solidario o subsidiario. 5.1.3. Subrogación de los herederos y el cónyuge sobreviviente en la calidad de beneficiarios. 5.1.4. La responsabilidad extracontractual derivada de la inejecución del seguro de vida grupo deudores. 5.2. Conclusiones. 6. La prescripción de las acciones y derechos en el contrato de seguro, visión jurisprudencial. 6.1. Implicaciones sustanciales. 6.1.1. Comentarios con respecto al momento en que se hace exigible la indemnización derivada del contrato de seguro. 6.1.2. Conocimiento de la póliza y sus condiciones. 6.1.3. Prescripción de la acción de nulidad del contrato de seguro basada en la reticencia o inexactitud del asegurado. 6.1.4. En cuanto a la interrupción de la prescripción. 6.2. Implicaciones procesales. 6.2.1. ¿Caducidad o prescripción de la acción de protección al consumidor? 6.2.2. ¿La aplicación del artículo 1081 del código de comercio se vio afectada en virtud de la entrada en vigencia de la ley 1480 del año 2011? 6.3. Conclusiones. 7. La libertad probatoria en el marco del contrato de seguro. BIBLIOGRAFÍA 


\section{CONFLICTOS RELATIVOS A LA SUSCRIPCIÓN Y LA VIGENCIA DEL CONTRATO DE SEGURO}

\section{Controversias en torno al régimen de anulabilidad del contrato de seguro por declaraciones inexactas y/o reticentes del tomador $o$ asegurado}

El presente estudio se encuentra dirigido al análisis de las discusiones más relevantes en torno a la nulidad relativa del contrato de seguro por virtud del incumplimiento del deber de la parte asegurada de declarar sincera y verazmente el estado del riesgo, en el marco de los pronunciamientos de la CSJ y la SFC.

\subsection{Situaciones derivadas del conocimiento o desconocimiento del riesgo por parte del asegurador}

En primer término, resulta oportuno anotar que las reticencias e inexactitudes son una aplicación del error como vicio del consentimiento dentro de la tratativa que le da el artículo 1058 del C.Co., que posee un régimen especial debido a la naturaleza misma de este contrato, en el cual se presenta una dependencia por parte del asegurador frente a su candidato a tomador o asegurado en cuanto a la información que este último pone en conocimiento del primero las circunstancias concernientes al estado del riesgo que pretende trasladar al Asegurador.

De este modo, el deber de declarar en forma sincera y veraz el estado del riesgo tiene como propósito salvaguardar el equilibrio técnico-económico que se debe predicar entre el riesgo asegurado y la remuneración establecida a favor del Asegurador.

Así las cosas, en el presente capítulo se abordará el estudio de las controversias más frecuentes en torno a la anulación del contrato de seguro por declaraciones inexactas o reticentes imputables al tomador o asegurado. 


\subsubsection{Obligatoriedad del tomador/asegurado de declarar el estado del riesgo frente a la no presentación de un cuestionario por parte del asegurador}

En relación con el asunto objeto del presente capítulo, la Sala de Casación Civil, (M.P. Esguerra Samper, 1976) con ponencia del magistrado José María Esguerra Samper, se pronunció al respecto. Su análisis se basa en responder a la siguiente pregunta: si el asegurador no somete al tomador a un cuestionario, ¿se encuentra éste obligado a declarar sinceramente el estado del riesgo para permitirle a aquel la expresión de un consentimiento exento de todo vicio?

Sobre el particular, la CSJ indicó que no es indispensable el cuestionario para llevar a cabo la declaración de asegurabilidad, y, por ende, la obligación de sinceridad y amplitud en la declaración por parte del tomador o asegurado se mantiene intacta. Lo anterior, basado en una interpretación literal del segundo inciso del artículo 1058 del C.Co., norma rectora de esta temática, el cual estima lo siguiente: Si la declaración no se hace con sujeción a un cuestionario determinado, la reticencia o la inexactitud producen igual efecto si el tomador ha encubierto por culpa, hechos o circunstancias que impliquen agravación objetiva del estado del riesgo.

Ahora bien, corresponde dilucidar el siguiente interrogante ¿es reticente el tomador o asegurado que al diligenciar el formulario excusa su falta de precisión y de verdad, en que no leyó ni entendió el mismo? Al respecto, la SFC (2014), (2014), (2014) y (2014) ${ }^{9}$, determinó que, efectivamente, se configura reticencia en estos casos, puesto que no debe el declarante dar informaciones con base en un formulario que no ha leído en su totalidad o que no ha entendido y, por lo tanto, corre con las consecuencias que esto genera, lo cual se acompasa con la carga de sagacidad y de información inherentes al ejercicio de la autonomía privada.

No obstante, el cuestionario debe ser claro, pleno y limitativo, $y$ sus preguntas no pueden ser muy generales o ambiguas, de modo que

9 En los casos expuestos, se estudió la procedencia de la nulidad relativa por reticencia en una póliza de vida grupo deudores. En estos, los declarantes firmaron el documento pre impreso aportado por la aseguradora, sin detenerse a leer lo que allí se indicaba; argumento usado a su favor para la defensa frente a la reticencia. En este sentido, la Superintendencia determinó que el hecho de no leer y firmar lo contentivo en la declaración de asegurabilidad no podría ser una razón válida para desvirtuar la reticencia, toda vez que al firmar el documento acepta lo plasmado en el mismo. 
puedan generar confusión en el declarante, y, en esta vía, reticencias o inexactitudes en la información recibida. (2013).

Por consiguiente, ni la ausencia de un cuestionario, ni malentenderlo o no leerlo darán lugar a sanear la reticencia o inexactitud derivada en que ha incurrido el declarante.

\subsubsection{Alcance del conocimiento presuntivo del asegurador derivado de las inspecciones del riesgo}

Al plantearse como problema el límite sobre el conocimiento presuntivo que debe poseer el asegurador derivado de las inspecciones que éste realice, la Sala Civil (Corte Suprema de Justicia, 1999), con ponencia de José Fernando Ramírez, advirtió que el conocimiento presuntivo del riesgo al tenor del inciso último del artículo 1058 del Código de Comercio, no puede entenderse total, porque como ya se dijo, la inspección directa del riesgo no supone el conocimiento cabal del mismo. Salvo en lo que, como indica el inciso en cuestión, conoció o debió conocer antes de celebrarse el contrato, o si, ya celebrado el contrato, se allanó a subsanarlos o los acepta expresa o tácitamente.

Vistas las cosas, resulta imperioso determinar cuándo el asegurador conoce o debe conocer el riesgo al que se expone. Para esto, la Corte, dentro del mismo fallo antes citado, señaló que la inspección supone el conocimiento de todas aquellas circunstancias que un asegurador diligente habría percibido con las inspecciones, o reconocimientos hechos en el caso concreto. Así, un examen médico efectuado por el asegurador durante el trámite de una solicitud de seguro de vida, conlleva el conocimiento de toda la información que razonablemente se obtiene con ese tipo de examen, no con otros. (Subrayado fuera de texto).

En este mismo sentido, la CSJ, con ponencia de Pedro Lafont Pianetta, sostuvo que en concordancia con lo descrito en la precedente providencia, la nulidad relativa derivada de las reticencias e inexactitudes no es siempre procedente, puesto que dado el carácter de profesional que posee la compañía aseguradora, es aceptable que en los casos en que por "la naturaleza del riesgo solicitado para que sea asegurado y por la información conocida y dada por el tomador, la compañía aseguradora, de acuerdo con su experiencia e iniciativa diligente, pudo y debió 
conocer la situación real de los riesgos y vicios de la declaración, mas sin embargo no alcanza a conocerla por su culpa, lógico es que dicha entidad corra con las consecuencias derivadas de su falta de previsión, de su negligencia para salir de la ignorancia o del error inicialmente padecido" (Corte Suprema de Justicia, 1995).

Esta posición, a su vez, fue reiterada en sentencia de Carlos Ignacio Jaramillo (Corte Suprema de Justicia, 2001), la cual analiza la procedencia de la nulidad relativa derivada de la declaración reticente o inexacta desde la óptica del asegurador negligente o culposo, denotando que éste, al momento en que conoció o debió haber conocido, saneó los posibles vicios derivados de la declaración, y desvirtuó la potencial sanción derivada del incumplimiento precontractual en cabeza del tomador. Esto, en virtud de su experticia que lo obliga a revisar a profundidad el riesgo a ser asumido cuando de éste se perciban situaciones sospechosas o anómalas de acuerdo con su experiencia.

Frente a esto, es innegable que surge una cuestión cuyo trasfondo es sumamente polémico, esto es, lo relacionado al saneamiento del dolo del asegurado reticente o inexacto por la negligencia del asegurador al momento de evaluar el riesgo. Esto se refleja a raíz de preguntarse: ¿hasta qué punto es posible que el dolo de una parte sea saneado por la negligencia o la culpa de su contraparte?

Basado en lo decidido por el Alto Tribunal, es plenamente valido un raciocinio según el cual la negligencia de la compañía, como experto en la materia, permite pasar por alto el comportamiento de quien realiza la declaración de asegurabilidad en el contrato de seguro.

En ese sentido, el profesor Andrés Ordoñez (El tratamiento civil de la mala fe del asegurado en el contrato de seguro, 2005), arguye, trayendo a colación las normas del C.C., que el dolo no vicia el consentimiento cuando las dos partes incurren en él. Expresado de otro modo lo anterior, el dolo es compensable cuando proviene de ambas partes. Empero, no es admisible proceder de igual forma cuando el dolo de uno de los contratantes concurre con la culpa del otro.

Asimismo, José Fernando Torres llega a concluir que, a raíz de la posición adoptada por la CSJ, es posible que el "deber de informarse 
termine sustituyendo al deber de información" (Deberes de información en la etapa pre-contractual a cargo del aseguros y candidato a tomador, 2003), y, por lo tanto, el principio de la ubérrima buena fe, tan asociado a este contrato, pase a un segundo plano.

No obstante, la línea argumentativa antes reseñada no ha sido de recibo para la jurisprudencia, cuyo hilo argumentativo se ha mantenido incólume. Basta observar, la sentencia de mayo de 2006 con ponencia de Silvio Fernando Trejos (M.P. Trejos Bueno, 2006).

Ahora bien, pese a no contar con pronunciamientos de la SFC sobre el tema antes esbozado, resulta oportuno introducir los puntos de discusión con la confianza que algún día se acuda a las normas civiles para precisar el alcance y efectos del artículo 1.058 del C.Co. en torno a esta polémica.

\subsubsection{Saneamiento de la reticencia o inexactitud derivado de la práctica de exámenes médicos}

Frente a los exámenes médicos, la Corte (Corte Suprema de Justicia, 2000), con ponencia de Jorge Castillo Rugeles, observó que la reticencia o inexactitud no es saneable por haberse realizado exámenes médicos y no ser determinada en los mismos, puesto que, el deber del declarante de declarar sinceramente el estado del riesgo subsiste, con el fin de salvaguardar el equilibrio en la ecuación prima - riesgo trasladado. De este modo, el examen médico es únicamente un medio para inspeccionar el estado del riesgo, pero éste no sustituye en ninguna medida la declaración del tomador o asegurado.

Al respecto, es relevante recordar lo señalado por la Corte (Corte Suprema de Justicia,1999), en donde indica que un examen médico efectuado por el asegurador durante el trámite de una solicitud de seguro de vida, conlleva el conocimiento de toda la información que razonablemente se obtiene con ese tipo de examen, no con otros.

En este sentido, en sentencia proferida por la SFC (2015) se determinó que, en caso de no solicitarse exámenes médicos por parte de la entidad aseguradora, la sanción establecida en el artículo 1058 resulta igualmente aplicable. Lo anterior con base en que la declaración que hace el tomador 
o asegurado subsiste a pesar de no contarse con exámenes médicos. Por ende, la declaración debe ser sincera y detallar el estado del riesgo en la mayor medida posible.

De lo anterior, si se observan a nivel general las dos posiciones examinadas, se concluye que la sola circunstancia del sometimiento a la práctica exámenes médicos [y, por extensión, a cualquier mecanismo de inspección del riesgo], no constituye un elemento que traslade la responsabilidad de conocer el estado del mismo a la aseguradora, salvo en los casos tratados anteriormente, en los cuales se reputa el reconocimiento presuntivo del Asegurador en torno a la entidad del riesgo que le fue trasladado.

\subsection{Relevancia de las causas y motivos por los cuales un tomador/ asegurado incurre en reticencia o inexactitud, al momento de aplicar las sanciones derivadas de dicha conducta}

En este punto, se debatirá partiendo de la pregunta: ¿se deben tener en cuenta los motivos por los cuales el tomador o asegurado incurre en inexactitudes y/o reticencias, con miras a exonerarlo de las consecuencias de su actuar?

Respecto a esto, la Sala Civil ha apreciado, con ponencia de Silvio Fernando Trejos, (Corte Suprema de Justicia, 2005), donde se ha señalado que no importan, entonces, los motivos que hayan movido al tomador para comportarse sin fidelidad a la verdad, incurriendo con ello en grave deslealtad que a su vez propicia el desequilibrio económico en relación con la prestación que se pretende de la aseguradora, cuando se le ha inquirido para que dé informaciones objetivas y de suficiente entidad que le permitan a ésta medir el verdadero estado del riesgo; sea cual haya sido la razón de su proceder, con intención o con culpa, lo cierto es que la consecuencia de su proceder afecta la formación del contrato de seguro, por lo que la ley impone la posibilidad de invalidarlo desde su misma raiz.

En el mismo sentido, en sentencia con ponencia de la magistrada Ruth Marina Díaz Rueda (Corte Suprema de Justicia, 2007), se resuelve 
que no importan los motivos que hayan movido al tomador o asegurado para faltar a la verdad en la declaración, puesto que su actuar afecta la formación del contrato de seguro, alterando las cargas económicas que de este se derivan. Por lo tanto, no es admisible analizar la subjetividad del actuar del declarante al momento de trasladar la correspondiente información al asegurador, puesto que su omisión a la verdad es objetivamente sancionada por los efectos nocivos que ésta produce.

Entonces, se observa que la posición de la CSJ, es clara al señalar que la reticencia e inexactitud se evaluara de manera objetiva, y no se tendrán en cuenta los motivos que dieron lugar a la misma. Posición que a su vez, ha sido recogida y adoptada por la Corte Constitucional (M.P. Gonzalez Cuervo, 2014) en sentencia cuyo contenido reproduce el extracto antes mencionado.

La SFC en uso de sus funciones jurisdiccionales $(2014)^{10}$, ha resuelto en igual sentido que la Sala Civil de la CSJ. En esta sentencia indicó que no importan los motivos por los cuales el asegurado o tomador declara en contra de la realidad, toda vez que debe salvaguardarse el equilibrio, $y$, en este sentido, se debe dejar sin efecto el contrato de seguro.

Del mismo modo, la SFC (2014) ${ }^{11}$ determinó que el tomador o asegurado, según sea el caso, debe actuar con absoluta lealtad al declarar el estado del riesgo, de lo contrario, como es ya obvio, el contrato quedará viciado de nulidad relativa, sin que se admitan consideraciones externas que pretendan exculpar al declarante de su falta.

De esta manera, tanto la CSJ como la SFC son unánimes en torno a que no se deben tomar en consideración los motivos por los cuales se cae en reticencia o inexactitud, sino que, por el contrario, basta su configuración para restarle validez al contrato de seguro.

10 Póliza de seguro de vida de deudores que pretendía ser afectada por la asegurada al sufrir una pérdida de capacidad laboral de $89 \%$. No obstante, la pretensión fue objetada por la aseguradora toda vez que consideraba que la asegurada fue reticente al no declarar la laringitis crónica y faringitis crónica que ésta padecía y cuyo conocimiento poseía antes de la fecha en la que realizo la declaración de asegurabilidad.

11 Contrato de seguro de vida en el que, al cabo de un tiempo, la asegurada tuvo una pérdida de calidad laboral del 96\%, situación que puso en conocimiento de la aseguradora para afectar la póliza, y cuya respuesta fue la objeción de la reclamación basada en una reticencia dado el conocimiento previo de los quebrantos de salud que la misma padecía al momento de celebrar el contrato. 


\subsection{La relación de causalidad entre la reticencia 0 inexactitud y el siniestro como elemento para dar lugar a las sanciones contempladas en el artículo 1058 del código de comercio}

En este punto, se plantea el siguiente interrogante: ¿la reticencia o inexactitud proceden únicamente cuando la distorsión con la realidad se configura en el siniestro, o, por el contrario, nacen desde el momento en que el riesgo se vio alterado a causa de dicha imprecisión?

En relación con este punto, se enfatiza que en pretérita oportunidad la Corte Constitucional al concluir la exequibilidad del artículo $1058 \mathrm{del}$ C.Co., (M.P. Arango Mejía, 1997), estableció que en atención a la naturaleza misma del negocio asegurador y ante la contratación 'en masa' de las pólizas de seguro, es imposible inspeccionar todos y cada uno de los riesgos que le pretenden ser trasladados, por tanto, cobra relevancia la información que le suministra el tomador o asegurado, la cual se erigen en su única fuente de conocimiento del riesgo, quedando a merced de la honestidad del declarante, so pena que el contrato se encuentre viciado de nulidad relativa desde el momento de su celebración.

No obstante, lo relevante en esta materia para la Corte consistió en que la sanción derivada de las reticencias o inexactitudes aplica sin importar si existe una relación de causalidad entre el siniestro acaecido y los hechos que no fueron puestos a consideración del asegurador, puesto que lo que se castiga es el desequilibrio contractual al cual se ve expuesta la compañía por virtud del tomador o asegurado, en incumplimiento al principio de ubérrima buena fe.

En ese sentido, la CSJ mediante sentencia con ponencia del Dr. Jorge Santos Ballesteros (Corte Suprema de Justicia, 2002), se enuncia que [la] reticencia acreditada en el proceso (...) no tiene porqué ser la causa del siniestro, dado que tal exigencia no la contempla ley-de conformidad con el artículo 1058 del Código de Comercio. (Subrayado fuera de texto).

A su vez, la sentencia de 1 de junio de 2007 (Corte Suprema de Justicia, 2007) resaltó que el vicio se genera independientemente de que el 
siniestro finalmente no se produzca como consecuencia de los hechos significativos, negados u ocultados por quien tomó el seguro ${ }^{12}$.

En esta materia, la posición de la SFC guarda correspondencia con el derrotero antes expuesto, en la medida en que ha reiterado que no debe existir relación alguna entre la reticencia o inexactitud y el siniestro acaecido para castigar a quien incurrió en la primera con las sanciones que contempla la ley.

Para la SFC (2014) ${ }^{13}$, así no exista relación entre los dos conceptos enunciados anteriormente, la nulidad procederá por tratarse de un vicio del consentimiento basado en el error. Asimismo, en otro pronunciamiento (2014), la SFC señaló que la relación causal que importa y que, para estos efectos, debe existir, no es, como sostienen los demandantes, la que enlaza la circunstancia riesgosa omitida o alterada con la génesis del siniestro, sino la que ata el error o el dolo con el consentimiento del asegurador.

En concordancia con esto, la Delegatura (2014) concluyó que lo que busca la norma es restablecer el equilibrio del contrato al momento en que fue celebrado, pues, es desde este momento en que nace el vicio proveniente del error, y no cuando ocurre el siniestro ${ }^{14}$. En idéntico sentido, pueden consultarse las sentencias proferidas dentro de los procesos $2014-0082^{15}$ y 2015-2221, providencias en las cuales se sostiene

12 Corte Suprema de Justicia. Sala de Casación Civil. M. P. Edgardo Villamil Portilla. Sentencia del 1 de septiembre de 2010. Expediente 05001-3103-001-2003-00400-01.

13 Póliza de seguro de vida de deudores cuya reclamación se realiza por parte de la cónyuge del asegurado por la muerte del mismo. La aseguradora objeta la reclamación dado que el asegurado no declaró que padecía de hipertensión arterial y dicha enfermedad no fue puesta en conocimiento de la aseguradora al momento de realizar la declaración de asegurabilidad. Por su parte, la cónyuge sostiene que la muerte del asegurado no fue producto de la hipertensión, y, por ende, no es procedente la declaración de nulidad derivada de la reticencia.

14 Oportunidad en la cual la SFC señaló: "Esto, con prescindencia de extemporáneas consideraciones sobre la necesidad de que la reticencia o inexactitud tenga relación de causalidad con el siniestro que haya podido sobrevenir, justamente porque lo que se pretende es restablecer o tutelar un equilibrio contractual roto ab initio, en el momento de celebrar el contrato de seguro, y no al acaecer el siniestro. La relación causal que importa y que, para estos efectos, debe existir, no es, como sostienen los demandantes, la que enlaza la circunstancia riesgosa omitida o alterada con la génesis del siniestro, sino la que ata el error o el dolo con el consentimiento del asegurador." (Subrayado fuera de texto).

15 Póliza de seguro de vida en la cual se elevó reclamación contra la aseguradora en virtud de la muerte violenta sufrida por el asegurado. La compañía decidió objetar en virtud a un comportamiento reticente en la declaración de asegurabilidad al no manifestar el padecimiento de asma en cabeza del mencionado asegurado. 
la opinión que se ha venido desarrollando; confirmando así, sin ninguna novedad, lo explicado anteriormente.

\subsection{Obligación a cargo del asegurador de verificar la información declarada por el tomador/asegurado}

Respecto a la verificación que eventualmente realiza el asegurador de la información aportada por el declarante surge el siguiente cuestionamiento: ¿el asegurador está o no en la obligación de verificar la información propuesta por quien declara el estado del riesgo? En la materia, la CSJ ha determinado que encontrándose probadas las reticencias e inexactitudes debe entenderse que procede la sanción prevista para esto, sin detenerse a examinar si se realizó o no obligación la verificación de la veracidad de lo expuesto en la declaración.

Al respecto, la Sala se pronunció en sentencia con ponencia del Dr. José María Esguerra Samper (M.P. Esguerra Samper, 1976), indicando que estando probadas reticencias o inexactitudes de parte del tomador del seguro en el cuestionario que le sometió la Compañia demandada, cabía decretar la nulidad relativa de la póliza de incendio, porque la ley no le imponía a dicha compañía el deber específico de verificar tales inexactitudes o de suplir las reticencias, en que hubiera podido incurrir, dando a entender que la compañía de seguros no tiene el deber legal de contrastar la información recibida con la realidad, y, por ende, la defensa del declarante no puede basarse en este argumento. (Subrayado fuera de texto).

Asimismo, esta corporación, siguiendo la misma tesis, resaltó en sentencia con ponencia del magistrado Álvaro García Restrepo (Corte Suprema de Justicia, 2016), que la aseguradora no tiene el deber, sino la facultad, de confirmar los datos que con ese fin aquél le suministre; y que, por lo mismo, la conducta de buena fe que la respectiva empresa asuma, no sirve para evitar que se produzcan los efectos que el legislador previó para la reticencia del asegurado, en particular, la nulidad relativa del respectivo contrato de seguro. Lo anterior con base en el principio de ubérrima buena fe, cuyo contenido debe irradiar de todo contrato de seguro por sus especiales características. (Subrayado fuera de texto). 
Por otro lado, esta misma corporación se pronunció en sentencia de 2002 (Corte Suprema de Justicia, 2002), argumentando que si bien no existe una obligación que sea impuesta por ley al asegurador para que éste verifique la información que le sea dada en virtud de la celebración de un contrato de seguro, en el marco de una declaración de asegurabilidad, existen casos en que debe revisarse la actitud de éste, toda vez que su calidad de profesional en el campo le obliga a tener un cierto deber de cuidado en cada caso específico. Así las cosas, traslada al juzgador el cargo de determinar, en cada caso, cual debió haber sido la posición tomada por la compañía respecto al deber de verificación acá expuesto.

En este sentido, dicho deber nace de un comportamiento sospechoso por parte del declarante, que genere desconfianza al asegurador, lo cual es explicado en la sentencia en el siguiente sentido: esta reticencia (...)debió conducir a que el Tribunal declarara la nulidad relativa del contrato de seguro, sobre todo porque del acervo probatorio recaudado aflora que la compañía de seguros no tenía motivo alguno que le generara desconfianza y le impusiera el deber profesional de auscultar el estado del riesgo aún más de lo que hizo, que fue examinar el estado de salud del futuro asegurado y exigir el concepto profesional del asesor y del gerente de la agencia o sucursal de la aseguradora, víctima por tanto de un engaño que le asaltó su buena fe. (Subrayado fuera de texto).

De lo precedente es destacable que para la Sala no existe una obligación en cabeza del asegurador de verificar la veracidad de lo aportado en la declaración del estado del riesgo, y, por lo tanto, no es procedente pretender sanear una reticencia o inexactitud con base en este argumento. Por el contrario, el contrato se entiende viciado siempre que haya reticencia, independiente de la observancia de lo aportado por parte de la compañía.

$\mathrm{Al}$ respecto, la $\mathrm{SFC}$ se ha pronunciado en diversos fallos cuyo núcleo esencial ha radicado en la no obligatoriedad en cabeza del asegurador de verificar la información aportada por el declarante.

Lo anterior se ve reflejado en distintos apartados de sentencias proferidas en cumplimiento de las funciones jurisdiccionales a su cargo, en donde se ha indicado, citando la sentencia C-232 de 1997, proferida por 
la Corte Constitucional, que no es exigible a la aseguradora la revisión detallada de los elementos que constituyen el riesgo, dada la celeridad de la práctica en que se desenvuelve el negocio aseguraticio (2014-0634). Esta posición es igualmente observada en sentencias de los procesos con radicados 2013-0542 y 2013-0545, cuya ratio decidendi gira en torno a la imposibilidad de imponer una obligación como la acá discutida, puesto que la práctica aseguraticia se lleva a cabo a velocidades que no permiten un examen detallado de todos y cada uno de los contratos celebrados y su contenido.

A su vez, en sentencia del proceso radicado número 2015-0819, se destaca el principio de ubérrima buena fe que permea los contratos de seguro. Por ende, es deber del tomador, o asegurado (en seguros de vida), declarar sinceramente y sin omisiones la información solicitada. De tal forma, traslada al declarante la responsabilidad inexcusable de contestar lo que se le requiera, de acuerdo con la realidad. Eliminando, de esta manera, cualquier responsabilidad de observancia por parte del asegurador, porque, de suponerse que la información suministrada es sincera, no sería viable entrar a determinar su fiabilidad.

Con base en lo observado anteriormente, es dable deducir que no hay variaciones en las posiciones encontradas en una y otra corporación. Las dos mantienen el mismo criterio frente al problema expuesto, y justifican sus decisiones basadas en los mismos argumentos, esto es, la celeridad que conlleva la práctica aseguraticia, y la ubérrima buena fe con la que debe actuar el declarante del estado del riesgo.

\subsection{Alcances del deber de información por parte del asegurador al tomador/asegurado respecto de la declaración del estado del riesgo}

En este capítulo, se procederá a estudiar lo relacionado con el deber de información del asegurador frente a quien declarará sobre el estado del riesgo, y, por lo tanto, se evaluarán las consecuencias jurídicas derivadas del deber de información que tiene la aseguradora frente a sus futuros tomadores o asegurados durante la fase previa a la celebración del contrato de seguro en los casos en que se presenta reticencia e inexactitud. 
En ese sentido, tal como lo indica Andrés Ordoñez (Ordoñez, 2012), el deber de información en el contrato de seguro es de carácter reciproco, lo cual se traduce en que, sobre el asegurador pesa el deber de informar al potencial tomador- en la etapa precontractual- el alcance de las coberturas, poner en conocimiento los condicionamientos de los amparos, informar sobre la aplicación del infra seguro o supra seguro en los seguros de daños y dar a conocer el alcance de las consecuencias derivadas de la declaración del estado del riesgo, con miras a prevenir reticencias o inexactitudes, entre otras manifestaciones del mencionado deber.

Frente a este punto, la Sala Civil de la CSJ (Corte Suprema de Justicia, 1999) señaló que si el tomador, a su vez, está en condiciones de conocer la información, dada su propia especialidad y el mundo de los negocios en que gira, la obligación de informar por parte de la aseguradora se morigera y queda reducida a aspectos eminentemente técnicos.

De lo anterior, se observa que, dependiendo de las características de la contraparte de la aseguradora dentro del contrato de seguro, se entenderá si la obligación de informar por parte de la aseguradora a este último se mantiene, o, por el contrario, disminuye.

Esto es tratado desde el punto de vista de la SFC, frente al especifico punto de las reticencias e inexactitudes cuando en sentencia del proceso 2014-0419 ${ }^{16}$ señaló que la declaración de incumplimiento del deber de información al momento de suscribir el cuestionario de asegurabilidad, en un seguro grupo vida deudores, no es suficiente para excluir de responsabilidad al asegurado por reticencia.

No obstante, dicha determinación obedeció que "la declaración surtida por la activa respecto de haber sido inducida a firmar la declaración de asegurabilidad sin información u orientación alguna no encuentra soporte en otros medios probatorios, por el contrario, obran en el plenario las tantas veces citadas solicitudes de certificado individual, que expresamente reconoció haber firmado e impuesto en ellas su huella dactilar.

16 Póliza de seguro de vida de deudores, que pretendía ser afectada por parte de la asegurada a raíz de una incapacidad total y permanente. Sin embargo, la compañía objetó en virtud a una reticencia derivada de la no declaración de hipertensión anterior a la declaración de asegurabilidad. 
Con respecto a las sentencias dictadas por la corporación en cuestión, en procesos 2014-0409 y 2015-0963, se infiere que la sola afirmación del asegurado de no haber sido informado sobre la firma del cuestionario de asegurabilidad no exonera a la parte asegurada de sustraerse a los efectos que la declaración de nulidad relativa comporta, salvo que se acredite en forma fehaciente alguna negligencia atribuida al asegurador en este sentido.

Sin perder de vista lo anterior, la doctrina, encabezada por Andrés Ordoñez (El tratamiento civil de la mala fe del asegurado en el contrato de seguro, 2005), se ha pronunciado frente a la responsabilidad derivada de la intervención de los intermediarios de seguros, principalmente, las agencias. Esto, puesto que podría llegar a considerarse que dicha intervención puede dar lugar a reticencias e inexactitudes, pero que, debido al entramado normativo existente es difícil determinar hasta qué punto puede o no la representación que ejerce la agencia limitar la responsabilidad del asegurado cuando éste ha sido reticente o inexacto en su declaración.

Por ende, dependiendo de las circunstancias precisas de cada caso se debe entrar a determinar la responsabilidad del intermediario y su eventual traslado al asegurador, de las situaciones que podrían configurar o no una reticencia o inexactitud que desemboque en la nulidad relativa del contrato de seguro.

\subsection{Actos que comportan declaraciones inexactas y/o reticentes}

En el presente capitulo se abordará, de manera general, distintas conductas de los tomadores o asegurados que se traducen en declaraciones inexactas y/o reticentes y, por consiguiente, tienen la virtualidad de anular el contrato de seguro con las consecuencias que ello comporta.

Para empezar, la Corte (M.P. Santos Ballesteros, 2002) consideró como reticencia la declaración falsa del asegurado sobre su posición laboral e ingresos en el momento de tomar un seguro de vida, afirmando que al tomador del seguro incumbe la carga precontractual de declarar sinceramente el estado del riesgo, es decir, aquellos hechos o circunstan- 
cias de significación que le permiten al asegurador sopesar la potencial siniestralidad en relación con el evento incierto materia del contrato, de modo que, conociéndola casi siempre por las informaciones del tomador, opte por asumir el riesgo y asi tasar adecuadamente la prima o desistir de la celebración del contrato de seguro.

Por su parte, la SFC en providencia dictada en proceso 2012-0035 destacó que cuando la compañía aseguradora incurre en error inducido por el asegurado, hay lugar a declarar la nulidad relativa del contrato por reticencia. Lo cual es a todas luces congruente con la sentencia antes citada, puesto que estos errores a los que induce el declarante con la información falsa o inexacta propuesta, conllevan a una alteración en la estimación del riesgo, y, por lo tanto, en la tasación de la prima, lo cual deja vulnerable a la aseguradora al no contar con todos los elementos necesarios para encuadrar el riesgo dentro de los de su especie, y calcular así su real probabilidad de ocurrencia.

Así las cosas, es dable concluir que los actos que constituyen reticencia o inexactitud no pueden ser limitados taxativamente, sino que, por el contrario, son innumerables y pueden predicarse en el contexto de cualquier clase de seguro y comprende infinidad de circunstancias.

\subsection{La carga de la prueba de la mala fe en casos de reticencia e inexactitud}

En lo que concierne a este aspecto, la SFC señaló en sentencia dentro de proceso 2015-0725 que es deber de la aseguradora probar la mala fe en los casos de preexistencia ${ }^{17}$ y reticencia en el contrato de seguro. Lo anterior con miras a imponer la sanción que prevé el C.Co. para este tipo de casos. Así, al alegarse de reticencia, se le impone al asegurador la carga de probar el conocimiento previo del asegurado y la mala fe con la que éste obró frente a su contraparte.

17 Al respecto, en sentencia T-670 de 2016 de la Corte Constitucional, con ponencia del magistrado Jorge Iván Palacio, se destacó la diferencia existente entre preexistencia y reticencia, según la cual, la última exige mala fe para concretarse, mientras que la primera es un hecho objetivo. Por lo tanto, a la aseguradora que pretenda alegar nulidad relativa del contrato en virtud de una reticencia, no le será suficiente probar una preexistencia, sino que, además, deberá acreditar la mala fe. 
En efecto, la SFC en sentencia de proceso 2015-1148 falló en igual sentido, reconociendo que es deber del asegurador, al momento de alegar la reticencia, probar la mala fe con la que actuó su tomador o asegurado en la declaración de asegurabilidad, con miras a imponer las sanciones previstas en la ley comercial. Esto, apoyado en sentencia de tutela de la Corte Constitucional (M.P. Vargas Silva, 2014), cuya tesis central indica lo reproducido por la SFC en los casos expuestos.

Sin embargo, respecto a este último fallo es relevante mencionar que es cuestionable el hecho que se aplique una sentencia de tutela, cuyos efectos son inter partes, para justificar una decisión de una controversia cuyos sustratos fácticos son disímiles. Sin embargo, esta es una tendencia que parece abrirse camino en los pronunciamientos de la Delegatura.

\section{Controversias asociadas a la delimitación contractual de los riesgos asumidos por el asegurador}

\subsection{De las exclusiones en el contrato de seguro}

Sea lo primero mencionar que, en el contrato de seguros existe el principio fundamental de libertad contractual, el cual le permite tanto al asegurador como al tomador decidir si contratar, o no, y las condiciones que regirán dicha relación contractual (artículo 1056 del C.Co.)

En ese sentido, si bien existen por definición normativa riesgos que, en principio, se encuentran excluidos, estos pueden ser objeto de cobertura a través de pacto expreso de las partes, tal como ocurre con los riesgos de guerra civil o internacional, motines, huelgas, movimientos subversivos o, en general, conmociones populares de cualquier clase, así como las erupciones volcánicas, terremoto o cualesquiera otras convulsiones de la naturaleza, denominados comúnmente como riesgos de índole catastrófica (art. 1105 C.Co.).

A su vez, existen riesgos que son inasegurables, aun si mediase acuerdo de las partes en ese sentido, tal como ocurre con el dolo, la culpa grave y los actos meramente potestativos del tomador, beneficiario y/o asegurado, los cuales por definición, se entienden excluidos 
de cobertura del contrato de seguro y no admiten pacto en contrario (artículo 1055 C.Co.)

El asegurador puede, salvo algunos casos legales muy puntuales, asumir a su arbitrio todos o algunos de los riesgos a los que se encuentra expuesto el interés asegurado ${ }^{18}$, supeditando dicha asunción al cumplimiento de ciertos requisitos; o, por el contrario, puede decidir si pacta exclusiones que lo liberarían de pagar la indemnización acordada, en caso de acaecer el riesgo asegurado.

A continuación, se presentarán las diferentes posiciones que han adoptado tanto la CSJ como la SFC, con relación a las exclusiones pactadas en el contrato de seguro y las exigencias que las mismas deben cumplir de acuerdo con lo pactado en la normatividad vigente y aplicable al contrato de seguros.

Como punto de partida, debemos precisar que la función principal de las exclusiones es delimitar el riesgo que asume la aseguradora por virtud del contrato de seguro. Precisando, además, que las exclusiones en esta materia tienen unas características puntuales establecidas en el artículo 184 del Estatuto Orgánico del Sistema Financiero, tales como que las mismas deben ser pactadas expresamente por las partes en la póliza, a partir de la primera página, en caracteres destacados, y que deben redactarse de forma tal que sean de fácil comprensión.

En consonancia con lo expuesto, la CSJ ha dado aplicación al EOSF, a la Ley 45 de 1990 y a lo establecido en las Circulares Externas 007 de 1996 y 076 de 1999, precisando también, que dicha normatividad es imperativa $^{19}$, de obligatoria observancia y por tal no es posible excusar el

18 En sentencia del 3 de marzo de 2015, la Superintendencia Financiera de Colombia, mencionó que: [El asegurado al momento de tomar el seguro de desempleo no se encontraba vinculado laboralmente con ninguna entidad. La Superintendencia encontró que existía una clara delimitación contractual del riesgo, en el sentido de que, si se quería afectar tal amparo, resultaba necesario contar con un contrato laboral vigente]. (Superintendencia Financiera de Colombia, 2015).

19 En sentencia de tutela del 25 de julio de 2013, la Corte Suprema de Justicia, con ocasión de un seguro de vida, precisó que las exclusiones deben estar en caracteres destacados en la primera hoja de la póliza, y no en las internas o en la caratula o en las condiciones generales, situación que no se cumplió por la compañía aseguradora, toda vez, que la misma alegó que tenías las excepciones en las condiciones generales. Igualmente, aclaró que la normatividad en la que se exigen los requisitos anteriores, no corresponde a normas supletivas, por el contrario, las mismas son imperativas. (Corte Suprema de Justicia, 2013) 
cumplimiento de las condiciones ${ }^{20}$, debido a que una cláusula pactada sin el cumplimiento de tales requisitos sería considerada a todas luces ilegal.

A título de obiter dictum, la CSJ sostuvo que las exclusiones pactadas en la póliza no deberían generar un desequilibrio en los derechos y en las obligaciones que para las partes surgen del contrato de seguro, so pena de que las mismas puedan considerarse cláusulas abusivas ${ }^{21}$ con las implicaciones reguladas en la Ley 1328 de 2009.

Como segundo punto, la SFC ha mencionado que tratándose de una póliza de daños que recae sobre un vehículo y además tiene pactada la modalidad "todo riesgo" 22 , las disposiciones legales le otorgan la facultad a las aseguradoras de seleccionar y asumir los riesgos de forma autónoma. En desarrollo de lo anterior, plantea igualmente dicha entidad, que las exclusiones delimitan contractualmente el riesgo y que en consecuencia pactarlas es perfectamente válido, siempre con el cumplimiento de los requisitos establecidos en la ley.

De lo anterior, la SFC ha sentado la regla a manera de obiter dictum que la compañía aseguradora, atendiendo unos parámetros económicos, técnicos y legales, puede asumir algunos riesgos a los que está expuesto el objeto asegurado, sin que esto equivalga a la introducción de cláusulas abusivas. Es así como dicha entidad reitera, que el legislador facultó a las partes a establecer cláusulas en el contrato que exoneren

20 Con respecto a las exclusiones pactadas a partir de la primera hoja de la póliza, es pertinente anotar que en sentencia del tutela del 29 de enero de 2015, la Corte Suprema de Justicia, en reiteración de sentencia de 2013, dispuso que no se cumplía con lo exigido en la ley, debido a que se pactaron exclusiones en los anexos. [Con ocasión de un seguro de vida cuyo asegurado falleció, los beneficiarios demandaron el pago de la indemnización y la aseguradora propuso como excepción la inexistencia de la obligación por encontrarse una exclusión pactada en la póliza. En segunda instancia, el tribunal dio probadas las excepciones de mérito y liberó a la aseguradora del pago de la indemnización]. (Superintendencia Financiera de Colombia, 2015).

21 En sentencia del 19 de diciembre de 2008, la Corte Suprema de Justicia, precisó que: “(...) la respectiva exclusión no debe generar un desequilibrio tal en el haz de derechos y obligaciones que para las partes surgen del contrato de seguro, (...) la mencionada estipulación puede considerarse como una cláusula abusiva" [Se tomó una póliza de equipo contratista y maquinaria para amparar la excavadora hidráulica; presentado el siniestro, el tomador reclamó y la aseguradora objetó argumentando que se había pactado como exclusión si el daño se generaba por una sobrecarga a la máquina]. (Corte Suprema de Justicia, 2008)

22 En sentencia del 17 de julio de 2014, la Superintendencia Financiera de Colombia se estudió que: [Una sociedad adquiere una póliza todo riesgo con el fin de amparar un vehículo el cual sufre un siniestro y el cual se encontraba en leasing a favor de la misma sociedad. El asegurado el pago del seguro y la aseguradora objetó argumentando que el siniestro se generó en una situación expresamente excluida en la póliza]. (Superintendencia Financiera de Colombia, 2014) 
a la compañía aseguradora del pago de la indemnización, siempre y cuando la realización del riesgo se circunscriba a la situación pactada como "exclusión"23.

Visto esto, es posible encontrar un punto de contacto en las tesis de ambas corporaciones, existiendo entre la tesis de la SFC y la de la CSJ, uniformidad en cuanto a la posibilidad de pactar exclusiones en el contrato de seguro, basada principalmente en la libertad que concede el C.Co. a las compañías aseguradoras de asumir a su arbitrio ciertos riesgos.

\subsection{De los riesgos inasegurables}

El C.Co. menciona como regla general que existen en el contrato de seguros los siguientes riesgos inasegurables ${ }^{24}$ : El dolo, la culpa grave $y$ los actos meramente potestativos del tomador, asegurado o beneficiario.

La aplicación de la regla antes mencionada fue objeto de estudio por parte de la SFC, en donde con ocasión de una póliza de tarjeta protegida integral ${ }^{25}$, manifestó que existió participación voluntaria del asegurado en la causación del siniestro (voluntariamente entregó el dinero retirado de su cuenta a unos "desconocidos"), situación que resulta como primera medida, extraña al amparo pactado en la póliza y finalmente, que correspondería per se a un riesgo inasegurable en virtud de lo establecido en el C.Co., toda vez que fue un acto potestativo del asegurado.

Por otro lado, la $\mathrm{CSJ}^{26}$ con ocasión de una póliza vida grupo en que el asegurado falleció, distinguió entre el suicidio consciente del incons-

23 En sentencia del 22 de junio de 2015, la Superintendencia Financiera de Colombia reiteró que: [Los beneficiarios de una póliza de Accidentes Personales reclaman a la aseguradora, con el fin de hacer efectivo el amparo de fallecimiento por muerte accidental. La aseguradora objeta mencionando que se encontraba excluida de cobertura en la póliza, si dicha muerte accidental se generaba como consecuencia de infracciones a normas de tránsito, situación que se encontró probada por la Superintendencia Financiera quien denegó las pretensiones de la demandante.] (Superintendencia Financiera de Colombia, 2015).

24 Artículo 1055 del Código de Comercio.

25 Sentencia del 8 de mayo de 2014, Superintendencia Financiera de Colombia. (Superintendencia Financiera de Colombia, 2014).

26 En sentencia del 25 de mayo de 2005, la Corte Suprema de Justicia, estudió que: [Los demandantes actuando en calidad de beneficiaria y de hijos legítimos, demandan a la aseguradora a pagar los saldos insolutos de un crédito tomado en vida por el asegurado. La aseguradora objetó el pago de la indemnización del seguro de vida grupo, argumentando falta de legitimación en la causa y la exclusión del suicidio.] (Corte Suprema de Justicia, 2005). 
ciente, según que la persona tenga la capacidad de comprender lo que está realizando, por tal motivo, si existe voluntad del asegurado o del tomador en quitarse la vida, la muerte no sería per se un riesgo asegurable. En consecuencia, los períodos de carencia se aplican al suicidio consciente o voluntario y no al inconsciente, porque en éste último el riesgo queda cubierto desde la época de la celebración del contrato de seguro, sin importar la época en que ocurra. En todo caso, concluye dicho organismo, le corresponde a la compañía aseguradora probar la voluntariedad o no del suicidio y así argumentar si es un riesgo que en efecto sería inasegurable.

En nuestra opinión, la tesis planteada por la CSJ no tiene asidero alguno, toda vez que cuando existe suicidio resulta claro que se encuentra inmersa la voluntad del asegurado en realizar el acto de quitarse la vida; tema diferente es si la misma se encuentra viciada, como quiera que tal persona no se encuentra en el uso de sus facultades completas y no le sería posible actuar con pleno discernimiento y total libertad. Es así como, existiendo voluntad del asegurado, nos encontraríamos dentro de la hipótesis planteada en el C.Co en lo relativo a los riesgos inasegurables y puntualmente a que los actos meramente potestativos del tomador, asegurado o beneficiario no podrían ser objeto de cobertura, pues se podría llegar a desnaturalizar lo que hoy se entiende como el contrato de seguro.

\section{El aseguramiento excepcional de la culpa grave en el contexto de seguro de responsabilidad civil}

$\mathrm{La} \mathrm{CSJ}^{27}$ con ocasión de la póliza de responsabilidad civil, no solo ha sostenido que la culpa grave es un riesgo asegurable, sino que, si es intención de la compañía aseguradora excluir tal riesgo, debería pactarlo expresamente en el contrato de seguro en virtud de la libertad contractual que a ella le asiste, toda vez, que de existir silencio en el texto de la póliza se entendería amparada.

27 En sentencia del 25 de mayo de 2005, la Corte Suprema de Justicia, estudió que: : [Los demandantes actuando en calidad de beneficiaria y de hijos legítimos, demandan a la aseguradora a pagar los saldos insolutos de un crédito tomado en vida por el asegurado. La aseguradora objetó el pago de la indemnización del seguro de vida grupo, argumentando falta de legitimación en la causa y la exclusión del suicidio.] (Corte Suprema de Justicia, 2005). 
De lo mencionado anteriormente, se podría pensar de una primera lectura, que existiría una contradicción entre el artículo 1127 del C.Co. en lo concerniente al aseguramiento de la culpa grave y con lo establecido en el artículo 1055 del C.Co. relativo a los riesgos inasegurables, toda vez que la Ley 45 de 1990 modificó el artículo 1127 sin entrar a armonizar tal reglamentación con lo establecido en el artículo 1055 del mismo Código. Sin embargo, esta discusión fue zanjada por la CSJ, quien mencionó que no existe tal contradicción, sino que por el contrario, son normas complementarias, toda vez, que para los seguros de responsabilidad civil es claro que la culpa grave resulta asegurable ${ }^{28}$.

Traemos a colación la postura de Gabriel Jaime Vivas ${ }^{29}$, la cual establece que el análisis de la culpa grave sería válido únicamente en el escenario de la responsabilidad contractual, toda vez, que es aquí donde sería aplicable la clasificación tripartita de culpa grave, culpa leve y culpa levísima. En ese sentido, no tendría asidero alguno hablar de amparos o exclusiones relacionados con tal culpa, en una póliza de responsabilidad civil extracontractual por ser esta figura incompatible con su naturaleza.

\subsection{Conclusión}

De conformidad con lo anterior, podemos concluir que, aunque el artículo 1055 del C.Co. estipule de manera expresa cuales son los riesgos inasegurables, tratándose del seguro de responsabilidad, el artículo 1127 del C.Co. consagra una excepción a la regla general, al establecer la posibilidad de que la culpa grave sea un riesgo válidamente asegurable y en consecuencia existiría congruencia con los artículos mencionados en el estatuto mercantil.

\section{Disyuntivas en torno a la interpretación del contrato de seguro}

Uno de los principales motivos por los cuales se presentan controversias entre tomadores, asegurados o beneficiarios y la entidad aseguradora, devienen en que las cláusulas del contrato de seguro no son la fiel muestra de

28 Ibídem

29 Vivas Díez, Gabriel Jaime, La aplicabilidad o pertinencia de una exclusión de culpa grave en el contexto específico de un seguro de responsabilidad civil extracontractual, 2015. 
las verdaderas intenciones de las partes, o que por ejemplo los articulados propician interpretaciones disímiles en su contenido y alcance, generando la posibilidad de que existan diferentes entendimientos al mismo articulado. En todo caso, dichas diferencias terminan por hacerse evidentes una vez acaecido el siniestro, implicando que se adopten posiciones que terminan por reñir en conceptos determinantes como amparos, coberturas y exclusiones. Ahora bien, cuando las controversias respecto del contenido de las cláusulas son llevadas ante un juez, este debe conocer y tener a la mano una técnica que le permita dotar de contenido las estipulaciones y así optar por una posición que zanje las diferencias existentes. De conformidad con lo anterior, es nuestra intención exponer las tendencias que sobre el punto mencionado existen en la jurisdicción colombiana.

\subsection{Breve exposición de las construcciones jurisprudenciales referidas a la técnica de interpretación del contrato de seguro}

Lo establecido en el artículo 822 del C.Co., permite que para los eventos donde se genere una controversia relacionada con el contenido y alcance del contrato de seguro, sean aplicables las reglas de los artículos 1613 a 1624 del C.C., las cuales dictan una serie de parámetros destinados a que el juez conozca la amplitud de una cláusula que se muestra ambigua y así definir si los hechos base de la pretensión se ajustan a lo estipulado.

Así, se puede verificar la existencia de pronunciamientos de la CSJ que datan de $1977^{30}$, en los cuales se afirmó que el contrato debería ser interpretado en contra de la entidad aseguradora. Sin embargo, durante ese año, la misma entidad realizó una modulación a esta regla, sosteniendo que la interpretación debería ser en favor del cliente. ${ }^{31}$

30 Sentencia del 21 marzo de 1977 la Corte Suprema de Justicia [La beneficiaria de un seguro de vida con anexo de doble indemnización por muerte accidental demandó a la aseguradora por el pago del anexo mencionado. La aseguradora se opuso al pago con base en el hecho de que la beneficiaria no probó que la muerte accidental no fue causada por otra persona. La Corte aplicó la interpretación del contrato en contra de la aseguradora por haber sido la redactora del documento] (1977).

31 Sentencia del 9 de septiembre de 1977, la Corte Suprema de Justicia [Los asegurados en un seguro de responsabilidad civil que amparaba las actividades de parqueo en sus bienes inmuebles fueron demandados por uno de sus clientes con base en el robo de un camión de su propiedad. La aseguradora, llamada en garantía, se opuso al pago con base en la interpretación de una cláusula del contrato en la cual se establecía que el dueño del parqueadero debía expedir un recibo. La Corte aplicó una interpretación a favor del asegurado con base en el principio de interpretación en contra del contratante que redacta el clausulado del contrato]: (1977) 
Ahora bien, en el año 1988 se estableció que dentro de los métodos de interpretación, debía tenerse en cuenta que el contrato de seguro cumplía una función económica y social, lo cual implicaba que no le era posible al fallador, por vía de interpretación extensiva, incluir riesgos que no estaban cubiertos ni excluir los que se hubiesen pactado en la póliza, precisamente porque para cumplir las funciones del contrato era necesario que la compañía aseguradora, tuviera certeza de los riesgos asumidos y como consecuencia de lo anterior, la interpretación que debía adoptarse debería ser la restringida ${ }^{32}$.

Partiendo de lo mencionado, la CSJ hacia el año 1998 estableció que la interpretación del contrato debía consultar tanto sus cláusulas generales como especiales, para de esta manera conocer el verdadero alcance de las estipulaciones. Sin embargo, no deja de llamar la atención que también se mencionó la prohibición de propiciar que las aseguradoras excusaran su responsabilidad, con base en la redacción de cláusulas confusas que, interpretadas desde la buena fe y la equidad, permitieran favorecer los intereses del asegurado ${ }^{33}$.

Para el año $2002^{34}$, la CSJ se pronunció respecto de la interpretación en equidad, aclarando que si bien ese criterio había sido usado para determinados casos, no era óbice para derogar todas las reglas de interpretación legales y jurisprudenciales dictadas hasta el momento, por lo mismo, tal entidad ratificó que la verdadera intención de los contratantes debía ser consultada y que la buena fe que debe regir en el contrato, no justificaba de ninguna manera la falta de cuidado del tomador y/o asegurado.

32 Sentencia del 23 de mayo de 1988, Corte Suprema de Justicia, [El beneficiario de dos seguros, de vida y de accidentes personales, reclamó el pago de las pólizas con base en el hecho de que el asegurado murió abatido por las heridas sufridas por arma de fuego utilizadas con ocasión a un robo en su lugar de domicilio. La Corte casó la sentencia por encontrar que el riesgo no se hallaba amparado en los contratos de seguro, aplicando una interpretación restrictiva de las cláusulas de cobertura] (1988).

33 Sentencia del 29 de enero de 1998, Corte Suprema de Justicia,. [El beneficiario de dos seguros, de vida y de accidentes personales, reclamó el pago de las pólizas con base en el hecho de que el asegurado murió abatido por las heridas sufridas por arma de fuego utilizadas con ocasión a un robo en su lugar de domicilio. La Corte casó la sentencia por encontrar que el riesgo no se hallaba amparado en los contratos de seguro, aplicando una interpretación restrictiva de las cláusulas de cobertura] (M.P. Jaramillo Schloss, 1998).

34 Sentencia de 21 mayo de 2002, Corte Suprema de Justicia, [La accionante demanda la cobertura de un seguro de autos por hurto del bien, a lo que la compañía decide objetar con base en que se podía verificar que el bien había sido objeto ilicitos anteriormente. Dentro del razonamiento de la Corte se establece que las interpretaciones en equidad son solo para casos especiales y que por ende debe darse prevalencia al contenido] (2002). 
Ese mismo año la CSJ, también abordó el estudio referido al entendimiento que debía darse a las palabras en un contrato de seguro, recordando así que las partes no podían regirse por la literalidad del documento únicamente, sino que debía preferirse al sentido que dotara de eficacia las cláusulas del acuerdo, lo cual implicaba el deber de consultar la naturaleza del pacto, corroborar la coordinación de las cláusulas con el resto de las estipulaciones y verificar la armonía general del documento ${ }^{35}$.

Como se puede observar hasta este punto, si bien la CSJ había dictado reglas de interpretación, no había expuesto una técnica completa que abordara todas las reglas y normas existentes. Sin embargo para el año 2002 la CSJ ${ }^{36}$, afirmó que si bien era cierto que debían indagarse las verdaderas intenciones de las partes, y que para eso se podían consultar anteriores negocios suscritos por los mismos extremos o averiguar por la aplicación práctica de un determinado clausulado, era necesario aclarar que de mantenerse la ambigüedad, resultaban aplicables los artículos 1613 a 1623 del C.C, y que solo subsidiariamente a la aplicación de estos, podría usarse lo establecido en el artículo 1624 de la misma codificación, que incluye las reglas de interpretación a favor del deudor, en contra del predisponente y la imposibilidad de alegar la propia culpa.

Si bien para ese momento los desarrollos jurisprudenciales habían establecido, en mayor o menor medida, reglas para la interpretación de los contratos, la tesis que venía inmersa al interior de los referidos pronunciamientos era que si la compañía aseguradora era la parte profesional del negocio, es viable pensar que para los eventos en que el seguro se contratara por adhesión, debían aplicarse principalmente los criterios contenidos en el artículo 1624 del C.C ${ }^{37}$, situación que,

35 Sentencia del 7 de mayo de 2002, Corte Suprema de Justicia. [Controversia sobre póliza de cumplimiento denominada de valor admitido en la que el tomador incumplió con el contrato garantizado y la compañía objetó basada en agravación de riesgo, contrato no cumplido y por no encontrarse demostrada la ocurrencia del siniestro, ni la cuantía de la pérdida. El fallo del tribunal niega las pretensiones propuestas por el tomador de la póliza utilizando la verificación de la totalidad de la póliza.] (2002).

36 Sentencia del 1 de agosto de 2002, Corte Suprema de Justicia,[ Una sociedad tomó una póliza de incendio sobre unas obras que se iban a realizar. Acaecido el siniestro, esto es, daños en unas tuberías, la aseguradora objetó el pago de la indemnización argumentando que tales bienes no se encontraban cubiertos por el seguro. La corte le da la razón a la compañía aseguradora argumentando que en ese seguro puntual no se encontraban cubiertos tales bienes y que por el contrario, los mismos se encontraban amparos por otro tipo de seguro tomado con otra aseguradora] (2002).

37 Sentencia del 4 de noviembre de 2009, la Corte Suprema de Justicia, Sala de Casación Civil, [Dentro de una póliza de seguro de transporte, se alega como fundamento del siniestro la "avería particular", consistente en ablandamiento y cambio de forma de los contenedores de medicamentos causados por 
como hemos visto, había sido definida como regla de interpretación subsidiaria.

Ahora bien, las reglas de interpretación del contrato de seguro también han sido tema de discusión dentro de la jurisprudencia de la Corte Constitucional, quien señaló en sentencia de tutela ${ }^{38}$, que la interpretación del contrato de seguro podía hacerse de una manera dúctil, siempre que la misma se realice con la finalidad de proteger derechos fundamentales de personas que se encuentren en estado de debilidad manifiesta. Al respecto de esta sentencia, no se establecen dentro de la misma las implicaciones o reglas que rijan la interpretación señalada (Corte Constitucional Colombiana, 2016).

Como se puede observar, existe una amplia variedad de sentencias referidas a la interpretación del contrato de seguros, y, debido a las múltiples modulaciones que han sufrido las tesis expuestas, no es posible en este momento afirmar que exista en Colombia un método y reglas claras e indiscutibles de interpretación del contrato de seguro. Sin embargo, es nuestra intención exponer las controversias que se han suscitado respecto de los mecanismos de interpretación señalados, para hacer evidente la necesidad de adoptar un criterio unánime.

\section{2. ¿Existe contradicción entre el método restrictivo y el método de contexto de interpretación de los contratos de seguro?}

Como se mencionó, desde el año 1998 la CSJ se refirió a la necesidad que la interpretación del contrato se guiara por un criterio restrictivo, justificado en que los aspectos técnicos y económicos del seguro demandaban la obligación de la compañía aseguradora de que el contenido de las cláusulas del contrato estuviera dotado de total claridad ${ }^{39}$.

el cambio climático del trasporte, que implico que se analizara la exclusión de "cambio climático" en una póliza contratada por adhesión.] (2009)

38 Sentencia del 16 de mayo de 2016, la Corte Constitucional dijo: [En este caso el accionante solicita el pago de un seguro de vida colectivo a raíz de una incapacidad total y permanente, el cual es objetado por reticencia. Debido a la especial situación económica de tutelante la Corte opta aplicar una interpretación que consulte los derechos fundamentales del asegurado, terminando por obligar a la aseguradora a reconocer el amparo.]

39 Providencia del 29 de enero de 1998 la Corte Suprema de Justicia [En esta providencia se analiza una póliza de transporte de mercancías y se hace un análisis de los objeto de cobertura en términos de cantidad de bienes, que evaluado a la luz de la cláusula generan la cobertura] (1998) 
Por otro lado, en los eventos de contratación por adhesión, donde el potencial cliente no tiene posibilidades reales de discutir el contenido de una póliza por estar prediseñados los clausulados, deben aplicarse de forma preferencial las normas de interpretación del Artículo 1624 del C.C.

Estos dos medios de interpretación: la restrictiva y la del artículo 1624 del C.C, han llegado a reñir en situaciones ${ }^{40}$ donde existe una clara intención de la entidad aseguradora de delimitar minuciosamente los riesgos, usa un contrato prediseñado, implicando que teóricamente sean aplicables los mecanismos de interpretación de restricción y los del artículo 1624 del C.C.

En ese sentido, la selección de un criterio de interpretación es sumamente importante para el juez, quien, con base en la selección de uno u otro mecanismo, se aproximará al contenido del contrato desde una óptica diferente. Un ejemplo de esta situación es la evidenciada en una sentencia emitida por el Consejo de Estado ${ }^{41}$, en la que se optó por extender al máximo la cobertura de la póliza, amparando riesgos que no estaban pactados y que no guardaban relación con el tipo de póliza contratada.

Es menester resaltar que este tema ha sido estudiado e incluso expuesto dentro de la justicia arbitral, que ha manifestado que la referida interpretación del Artículo 1624 debe aplicarse únicamente en caso de que exista ambigüedad de una cláusula en un contrato de adhesión, y que por ende, no puede constituirse en una regla aplicable a toda controversia máxime cuando lo relevante es mantener la viabilidad técnica y financiera del contrato de seguro, por esta razón resulta idóneo aplicar la interpretación restrictiva que también se rige por un estudio de la naturaleza e integralidad del contrato.

40 Laudo arbitral del 15 de diciembre de 2009. Quala S.A. VS Chubb [Dentro del presente caso se discutió si era factible, que por vía de interpretación contextual, el amparo inicialmente pactado se analizara a la luz del iter criminis y no solo el hecho puntual base de la cobertura.]

41 Sentencia del 28 de febrero de 2017, el Consejo de Estado, Sala de lo Contencioso Administrativo. [La aseguradora otorgó una póliza con el objeto de amparar la ejecución del contrato. Un ciudadano en ejercicio del medio de control de reparación directa, solicitó que se le pagaran los perjuicios ocasionados por el servicio prestado por el hospital. El Consejo de Estado falló mencionando que la aseguradora debería pagar los perjuicios ocasionados, toda vez que era evidente que, si bien en ninguna de las distintas pólizas se menciona taxativamente la responsabilidad civil extracontractual como un riesgo amparado, lo cierto es que, dicho riesgo se encontraba inmerso en los descritos como prestación y calidad en el servicio.] (2017). 
Ahora bien, a la discusión anteriormente planteada debe adicionársele el contenido de la Ley 1328 de 2009 y de la Ley 1480 de 2011, donde a partir de la consagración de los derechos de consumidor, viene a implementarse la regla de que tanto la ley como el contenido de los contratos, deben interpretarse a favor de este último.

\subsection{La incidencia de los criterios de interpretación en favor del consumidor contenidos en la Ley 1480 de 2011}

Si bien es cierto que la Ley 1328 de 2009 es una norma especial que aplica al sector asegurador, no es menos cierto que, con la entrada en vigencia de la Ley 1480 de 2011 se implementaron reglas que cambiaron el panorama legal de interpretación y contenidos de los contratos suscritos por consumidores. Es precisamente a partir de los artículos 2 y 34 de la Ley 1480 de 2011, donde se establece un nuevo sistema de interpretación, puesto que, allí se establece que tanto la ley como el contenido general de los contratos deberán interpretarse de manera favorable al consumidor.

Ahora bien, los referidos artículos del estatuto general de protección del consumidor también establecen que de existir una duda derivada del contenido de dos clausulas, deberá aplicarse la más favorable a los intereses del consumidor, todo lo cual viene a cambiar completamente el panorama que hasta este momento había sido construido por la CSJ.

Finalmente, si bien el contenido de las normas antes mencionadas resulta aplicable a los casos estudiados por la SFC, es menester precisar que tal entidad, al interior de sus providencias no ha realizado un análisis específicamente dedicado al contenido del principio "interpretación en favor del consumidor". Por el contrario, de manera general y muy limitada ha establecido que las cláusulas del contrato de seguro deben interpretarse siguiendo esta regla, pero, sin detenerse al estudio en detalle sobre este punto. 


\section{Análisis critico y comparativo en torno a la terminación 'automática' del contrato de seguro por mora en el pago de la prima}

En el presente capítulo abordaremos lo concerniente al análisis conceptual y jurisprudencial sobre los efectos de la mora del tomador (o asegurado) en el pago de la prima, veremos, además, diversas discusiones que se han planteado en el tribunal de cierre de la justicia ordinaria y que paralelamente han cursado ante la SFC, incluyendo por supuesto algunas menciones de derecho comparado en esta materia.

\subsection{Sobre la terminación automática por mora y su diferencia con la revocación del contrato de seguro}

En lo que tiene que ver con la terminación automática del contrato de seguro por mora, es importante tener en cuenta que la CSJ ha distinguido en diversas sentencias la diferencia entre el concepto de revocación del contrato de seguro y terminación por mora en el pago de la prima.

Entre tales conceptos, existe una diferencia normativa, pues cada una de ellas produce consecuencias jurídicas distintas; la primera - la revocación del contrato de seguro - tiene necesariamente que ser una decisión de alguna de las partes que no implica el incumplimiento en las obligaciones contractualmente adquiridas con la celebración del contrato de seguro.

En lo que respecta a la segunda - la terminación automática por mora en el pago de la prima - es per se la consecuencia inmediata del incumplimiento del tomador en una de las obligaciones que surge con ocasión de la celebración y perfeccionamiento de la relación aseguraticia entre las partes.

$\mathrm{Al}$ respecto la CSJ ha indicado que la mora en el pago de la prima no puede tener como consecuencia la revocación de la póliza de seguro por parte del asegurador, puesto que las consecuencias jurídicas derivadas de la misma son completamente distintas a las de la figura de la terminación automática pues esta última se produce ipso iure y no depende de la voluntad o de la intención de las partes (Corte Suprema de Justicia, 2007) ${ }^{42}$.

42 Proceso en el que se discutió acerca de la obligación de la entidad bancaria como tomador de una póliza de tipo colectivo de pagar la prima, con independencia de la posibilidad de descontar al 
En igual sentido, la SFC ha señalado que la terminación se establece como una sanción, salvo que exista una disposición legal en contrario -como es el caso de la ley 80 de 1993- pues se impone por ministerio de la ley, lo cual, de plano impide la posibilidad de que sea pactado en contrario por las partes manteniendo vigente el contrato de seguro ( $\mathrm{Su}-$ perintendencia Financiera, 2002).

Sin embargo, al respecto es necesario tener en cuenta que no obstante ello, la Corte establece que, en cualquier caso, el asegurador está en facultad de exigir el pago de la prima devengada por la parte proporcional al tiempo no corrido del riesgo, sumados los gastos de expedición, sin que ello afecte o condicione la terminación ${ }^{43}$.

\subsection{Divisibilidad de la póliza y sus certificados a efectos de la aplicación de la terminación por la mora en el pago de la prima}

La posición de la SFC acerca de la divisibilidad o no del contrato de seguros determinada por la póliza ${ }^{44}$ y los certificados o anexos que hacen parte integrante de la misma, reitera que dicha discusión quedo absolutamente zanjada con la modificación realizada al artículo 1068, pues, el legislador evidentemente usó la conjunción disyuntiva "o" estableciendo que, será una o la otra -la póliza o un anexo de la misma-, cuya mora producirá la terminación del contrato.

De esta manera, la posición de la $\mathrm{SFC}$ en sus pronunciamientos ha estado en consonancia con lo establecido por la CSJ en Sentencia del 18 de diciembre de 2009 (Corte Suprema de Justicia, 2009) ${ }^{45}$, al encontrar tal claridad en el articulado de la norma comercial, cuestión que ha quedado plasmada tanto en el órgano de cierre de la jurisdicción ordinaria como en el ente de control particular para la actividad aseguradora.

asegurado o no el cobro por el valor de la misma. A efectos de la terminación el tribunal se manifestó indicando que, si bien la asegurada había autorizado el débito, ello no ponía fin al compromiso de pago, pues tenía la entidad la posibilidad de obtener el pago por la vía judicial.

43 Ibídem.

44 Que bien podría denominarse únicamente la carátula a su documento inicial.

45 Sentencia en la que se aborda la discusión acerca de la procedencia de la terminación por mora de cada uno de los certificados considerados individualmente o si por el contrario la mora en cualquiera de ellos es susceptible de poner fin al contrato de seguro como un todo. 


\subsection{El obligado al pago de la prima en seguros tomados por cuenta de un tercero}

En los seguros colectivos, es común encontrar la disyuntiva acerca de quién es el obligado a pagar la prima, si el tomador - cuya obligación además es legal ${ }^{46}$ - o el asegurado - a quien en el caso de seguros tomados por bancos le debitan automáticamente el valor de la prima-sin embargo la Corte Suprema de Justicia, ha señalado sobre el particular que teniendo en cuenta que en este tipo de seguros, el tomador es el banco, es este mismo el obligado al pago de la prima; debe el tomador -a juicio de la corte- realizar el pago de la prima, incluso cuando no le ha sido trasladada ella por parte del asegurado (Superintendencia Financiera, 2014) ${ }^{47}$.

A pesar de esto, recientemente en sentencia de este año, la Corte ha cambiado su posición - a nuestro juicio de manera lógica - al establecer que no puede el tomador en todos los casos, correr con la carga de asumir indefinidamente el pago de la prima que el asegurado, encontrándose en deber de hacerlo, no ha trasladado incumpliendo así los pagos (Corte Suprema de Justicia, 2017) $)^{48}$.

Contrario a ello, la SFC ha dicho "La prima es un elemento esencial del contrato de seguro, es decir, que ante su no pago, el contrato deja de existir por terminación automática. Cuando para su pago se ha autorizado un débito automático de los depósitos del asegurado en una entidad financiera, debe contarse con los fondos suficientes para ello, sin que esta resulte responsable por el pago cuando no se cuenta con los mismos, pese a haberse informado previamente del deber de contar con dinero en la cuenta y haberse realizado un número importante de intentos sin resultado positivo." (Superintendencia Financiera, 2016)

46 ARTÍCULO 1066 del C.Co. El tomador del seguro está obligado al pago de la prima. Salvo disposición legal o contractual en contrario, deberá hacerlo a más tardar dentro del mes siguiente contado a partir de la fecha de la entrega de la póliza o, si fuere el caso, de los certificados o anexos que se expidan con fundamento en ella.

47 Sentencia en la que se decide acerca de la facultad del tomador de acudir a las vías judiciales para realizar el cobro de la prima al asegurado, reiterándose que es el tomador de la póliza de seguro el obligado al pago de la prima, aun existiendo convenio en contrario suscrito entre dicho tomador y asegurado. Procediendo la terminación del contrato de seguro y debiendo asumir el tomador el pago de la indemnización.

48 Se demanda a la entidad bancaria por el incumplimiento de sus obligaciones al no pagar las primas en su totalidad y no notificar a la asegurada, sin embargo, se absuelve al banco pues el asegurado asumió el compromiso de pago. 


\subsection{El deber de informar sobre la terminación del contrato de seguro}

Ahora bien, en cuanto al deber de información, respecto de la terminación del contrato de forma automática, la $\mathrm{SFC}^{49}$ se ha pronunciado encaminada a incluir allí el principio de la ubérrima buena fe que rige el contrato de seguro, afirmando que "...la falta de compromiso del tomador en la realización de su obligación principal produce el rompimiento de ese principio de la buena fe; por lo tanto, es indispensable que las partes reunidas en un contrato de esta índole desplieguen una actividad con lealtad para su ejecución, gobernada por la diligencia y el cuidado necesarios, ya que todo acto contrario a la misma, como sería la constitución en mora por el tomador, agrede la confianza del asegurador en el desarrollo del contrato y frente a los riesgos que éste ha asumido" (Superintendencia Financiera, 2013).

También encontramos que la SFC, en lo que tiene que ver con la autorización de débito automático de las cuentas o productos de los asegurados, cuando quien comercializa y toma el seguro es una entidad bancaria, se ciñe al análisis exegético de la disposición del artículo 1066 del C. $\mathrm{Co}^{50}$. en cuanto a que el llamado a realizar el pago de la prima es el tomador del seguro.

Pero, por otra parte, cuando el tomador es el mismo asegurado y la entidad bancaria actúa únicamente como intermediario en la colocación de las pólizas de seguros facilitando a sus clientes la realización del pago, es el tomador el llamado a realizar el pago de la prima debiendo informarse sobre los términos y condiciones de la celebración del contrato, pues es su carga mínima en este tipo de negocios.

49 “...el precitado artículo 1068 establece una sanción que se traduce en una causal de terminación del contrato de seguro producto del incumplimiento de las obligaciones contractuales contraídas por el tomador o asegurado y que opera ope legis, esto es, de pleno derecho, en la medida que no requiere mediación de la voluntad de las partes para que surjan a la vida jurídica los efectos plasmados en la norma. En este aspecto requiere precisarse que no puede por tal razón darse al certificado de cancelación de saldos que obra a folio 388 un carácter constitutivo de la terminación, por cuanto esta no requiere de declaración o estipulación alguna, por cuanto, como se anotó, opera por ministerio de la ley."

50 ARTÍCULO 1066 del C.Co. El tomador del seguro está obligado al pago de la prima. Salvo disposición legal o contractual en contrario, deberá hacerlo a más tardar dentro del mes siguiente contado a partir de la fecha de la entrega de la póliza o, si fuere el caso, de los certificados o anexos que se expidan con fundamento en ella. 
El deber de información de los consumidores, en lo que tiene que ver con la celebración del contrato de seguros, implica que el consumidor debe informarse de manera suficiente acerca de las particularidades de lo que contrata, determinando sus características generales, y conociendo de manera suficiente el producto, sus derechos como consumidor determinados por la particularidad del negocio jurídico que realizará, el costo, las desventajas de dicho producto frente a otros de similares características en el mercado, sus obligaciones como consumidor, y, en general, todas aquellas circunstancias que lo llevan a la contratación del seguro y a tomar la decisión de realizar dicha adquisición a través de determinada forma de pago.

\subsection{Conclusión}

La terminación Ope legis que se consignó en la Ley 45 de 1990, no requiere de aviso o notificación al tomador o asegurado, pues al ser terminación de derecho, no media la voluntad de las partes del contrato, a tal punto que, el asegurador, al haber realizado su labor diligentemente (asumir el riesgo, expedir la póliza y realizar oportunamente los cobros), pierde todo control sobre tal situación. Es deber recordar que el inciso último del artículo 1068, establece dos supuestos, el primero, la imperatividad del artículo; el segundo, la prohibición de pactar en contrario (Superintendencia Financiera, 2013) ${ }^{51}$.

\section{Controversias asociadas al seguro de vida grupo deudores}

\subsection{Legitimación en la causa de terceros que no son parte en el seguro de vida grupo deudores}

En los contratos de seguro, la legitimación en la causa tiene especial relevancia en las pólizas de vida grupo deudores tomadas con ocasión de créditos o mutuos con entidades financieras. La legitimación en la causa

51 Posición acogida por la Superintendencia Financiera de Colombia "existía pleno conocimiento del consumidor respecto de las condiciones en que debía cumplir su obligación, por lo que no es predicable que la conducta de la aseguradora pudiere generar una alteración en las condiciones contractuales, como se pretende por el actor, máxime cuando las consecuencias de su incumplimiento se encuentran establecidas en la ley sin que las partes puedan alterar tal disposición, cuando ocurre el supuesto fáctico de la mora". 
tiene que ver con el derecho u obligación sustancial que tiene la parte procesal para actuar o ser vinculado en el proceso. En este sentido, la discusión es relevante para el caso de los seguros vida grupo deudores, en la medida que se analizan conceptos como el interés asegurable, la calidad de parte en el contrato de seguro, el principio de la relatividad de los contratos y la subrogación en la calidad del beneficiario oneroso.

En los seguros de vida grupo deudores, la entidad financiera es el tomador y beneficiario oneroso del seguro, y, el deudor es el asegurado. Su carácter es colectivo, por tanto, el grupo de personas aseguradas está compuesto por los deudores de la entidad financiera. Los amparos que generalmente cubre el seguro son los de muerte accidental, homicidio, suicidio e incapacidad total y permanente.

El interés asegurable en los seguros de vida grupo deudores se encuentra en cabeza del banco ${ }^{52}, \mathrm{y}$, en consecuencia, se ha entendido que la entidad financiera actúa por cuenta propia ${ }^{53}$.

En contraste, sostener la tesis contraria ${ }^{54}$, en la cual el interés asegurable de la póliza vida grupo deudores le corresponde al asegurado, formularía nuevos interrogantes tales como la posibilidad de que los

52 Según el artículo 1137 literal 3) del C.Co., el banco tiene interés asegurable en la vida... "de aquellas cuya muerte o incapacidad pueden aparejarle un perjuicio económico, aunque éste no sea susceptible de una evaluación cierta".

53 No se trata de un seguro por cuenta de un tercero, porque la entidad financiera al adoptar el carácter de tomador del amparo actúa como titular de su propio interés asegurable y que se deriva del perjuicio que pueda representarle la muerte o la incapacidad total y permanente de su deudor, por lo que no contrata el amparo por cuenta o en interés de ese deudor aunque el importe de la prima sea trasladado a él. Claro está que se trataría de una hipótesis distinta, si el deudor asumiera la iniciativa y, por tanto, contratara el seguro en interés de su acreedor para que en caso de su fallecimiento o incapacidad, pudiera hacer efectiva la póliza en cuanto al saldo impagado de la deuda en ese momento. (Legitimación de la viuda y de los herederos bajo el seguro de vida grupo deudores, 2013).

54 La CSJ en Sentencia de 30 de junio de 2011 ha indicado que: "El acreedor obra por cuenta ajena, pues traslada al asegurador un riesgo que en principio no es propio, sino que está en cabeza del deudor. Valga memorar que "lo ordinario, lo general, es que 'el tomador' celebra el contrato de seguro sea en su propio nombre o por medio del representante pero, en todo caso, 'por su propia cuenta', para proteger 'su propio interés' sobre la cosa o la vida asegurados, sobre el 'objeto' asegurado. En el 'seguro por cuenta', en cambio, el contrato está destinado a cubrir, básica y, las más de las veces, prioritariamente, un interés asegurable 'ajeno', el interés de un 'tercero' en la cosa asegurada o a la cual se hallan vinculados los 'riesgos' objeto del contrato... es... el caso del acreedor hipotecario o prendario que, interesado en la seguridad de su acreencia, contrata el seguro 'por cuenta' de su deudor...". [ La demandante demandó al banco con quien había contratado un préstamo aduciendo que dicha entidad financiera incumplió ese acuerdo de voluntades, al no amparar la totalidad del préstamo con el seguro de vida grupo deudores que tomó en nombre de aquéllos] (M.P. Villamil Portilla, 2011) 
herederos del asegurado y el cónyuge supérstite ostenten dicho interés en virtud de los derechos de sucesión y la normas relativas al haber social en la sociedad conyugal. No obstante, el asegurado no puede ser el interesado porque el banco no ha contratado el seguro en interés de su deudor, todo lo contrario, lo ha hecho en interés propio y por ello la entidad financiera ostenta la doble calidad de tomador $^{55} \mathrm{y}$ beneficiario oneroso.

Una vez ocurre el siniestro, esto es, la muerte del asegurado, la entidad financiera tiene a su disposición múltiples recursos y soluciones a las cuales puede recurrir. El banco puede proceder a reclamar el seguro vida grupo deudores, solicitar a los codeudores, deudores solidarios y avalistas del difunto deudor el pago de las obligaciones que estaban a su cargo, o, puede contactar al cónyuge supérstite y a los herederos del deudor para que paguen la deuda del causante.

Cuando el banco opta por la tercera de estas opciones, los herederos y el cónyuge supérstite, ante la posibilidad de librarse de la acreencia del difunto, y, conociendo la existencia del seguro de vida grupo deudores, presentan ante la jurisdicción civil demandas a las aseguradoras para reclamar el pago del seguro. En este escenario, se ha discutido la legitimidad de los herederos y el cónyuge supérstite, como terceros del contrato de seguro, para reclamar ante la aseguradora el pago, a favor de ellos o del banco, del valor contratado en la póliza de vida grupo deudores.

\subsubsection{Casos analizados por la jurisprudencia}

La legitimidad en la causa del cónyuge supérstite y los herederos del asegurado del contrato de vida grupo deudores ha sido dilucidada por las autoridades jurisdiccionales en el marco de tres hipótesis.

La primera se presenta respecto de los codeudores, deudores solidarios y avalistas que pagan la deuda al banco y luego buscan reclamar por vía jurisdiccional el pago del seguro vida grupo deudores.

55 “...el interés asegurable dice relación al derecho que asiste a un individuo para asegurar a otro contra riesgos personales o para asegurarse a sí mismo. Problema jurídico distinto es la designación de beneficiario. (Ossa G., 1963). 
La segunda contempla la reclamación del seguro por parte de los herederos y el cónyuge supérstite. Aquí, los demandantes pretenden el pago a su favor. En su momento, la jurisprudencia sostuvo la tesis de que existía legitimación en la causa en virtud de que los herederos y el cónyuge supérstite se subrogaron en la calidad de beneficiario, toda vez que cancelaron con su patrimonio la deuda del asegurado.

Por último, el tercer supuesto se presenta cuando los herederos y el cónyuge supérstite reclaman judicialmente a la aseguradora el pago del seguro al banco, con base en la acción de responsabilidad civil extracontractual. En este entendido, los demandantes pueden solicitar el pago a su favor, porque pagaron con su patrimonio la deuda del asegurado.

\subsubsection{Inexistencia de legitimación en la causa del codeudor solidario o subsidiario}

El codeudor es tercero respecto del contrato de seguro y su pago al banco podría llegar a considerarse como una subrogación ${ }^{56}$. La Jurisprudencia de la C.S.J ha entendido que la subrogación del deudor solidario, en razón al pago realizado al banco, no se extiende a los derechos que este último tiene con relación a la aseguradora como beneficiario oneroso ${ }^{57}$.

\subsubsection{Subrogación de los herederos y el cónyuge sobreviviente en la calidad de beneficiarios}

Por otra parte, los herederos y el cónyuge supérstite ${ }^{58}$ han reclamado a su favor el pago del seguro de vida grupo del asegurado, alegando la existencia de la subrogación en los derechos del banco. Este fue el caso

56 De acuerdo con los artículos 1666 a 1671 del C.C.

57 La Sentencia de 23 de marzo de 2004 sostuvo con atino que: "hay un deudor que paga y por esa razón se da la subrogación en los derechos del acreedor satisfecho, pero no alcanza la misma para que se le transmitan los derechos como beneficiario del seguro de vida deudores contra la aseguradora tercero para el caso-... cuanto que no se le puede calificar de tercero que se haya obligado solidaria o subsidiariamente como lo exige el artículo 1670 del C. Civil..." [En este caso el asegurado y su hijo firmaron como deudores solidarios el pagaré. Ante la muerte del asegurado, su hijo pagó la deuda, y, habiendo objetado la aseguradora la reclamación del banco, demandó alegando la calidad de beneficiario del seguro. El tribunal en segunda instancia reconoció al codeudor como subrogatario y la Corte casó la sentencia en última instancia] (M.P. Gonzalez Cuervo, 2014).

58 Teniendo en cuenta los pronunciamientos de la Corte Constitucional en la materia, lo mismo puede ser dicho del compañero permanente supérstite. Al respecto puede consultarse la Sentencia C-844/10 M.P. María Victoria Calle Correa. (M.P. Calle Correa, 2010). 
de la Sentencia de 25 de mayo de $2005^{59}$, en donde la Corte consideró que el artículo 1670 del C.C. le era aplicable a la aseguradora y, en consecuencia, aquel que paga la deuda se subroga en los derechos del banco respecto del contrato de seguro ${ }^{60}$.

Este caso marcó un cambio en la jurisprudencia de la Corte ${ }^{61}$ puesto que, a partir de este fallo, se ha entendido que los herederos y el cónyuge supérstite están legitimados en la causa para cobrar el seguro de vida grupo deudores del causante asegurado, ya sea por causa de la subrogación, en materia contractual o en virtud de la responsabilidad extracontractual.

\section{La aplicación del artículo 1670 del C.C. a la aseguradora desconoce} quién tiene interés asegurable en el seguro contratado. En el seguro de vida grupo deudores se asegura el riesgo de muerte del deudor, y el interés asegurable del contrato radica en cabeza del acreedor, puesto que fue él quien contrato el seguro. ${ }^{62}$ La compañía aseguradora no se obligó, en

59 La Corte manifestó: "que los demandantes adquirieron la calidad de beneficiarios, a título oneroso, porque esa era precisamente la posición del Banco Cafetero en el contrato de seguros, que no es lo mismo a que fueran beneficiarios directos..." [La cónyuge supérstite, en calidad de beneficiaria subsidiaria, $\mathrm{y}$, los herederos demandaron a la aseguradora el pago del seguro de vida grupo deudores una vez que el asegurado cometió suicidio y esta objetara la reclamación del banco. Cuando la entidad financiera se enteró de la objeción, se limitó a cobrar a los herederos y la cónyuge del causante el valor del crédito, deuda que fue cancelada en su totalidad por los últimos.]

60 No obstante aclara la Corte, en concordancia con la Sentencia de 23 de marzo de 2004, que: "Distinto es que los demandantes o uno de ellos hayan pagado la obligación como codeudores solidarios del causante, caso en el que el pago realizado no les otorga la calidad de beneficiarios del seguro de vida grupo deudores que tomó el acreedor inicial, porque con motivo de la solidaridad pasiva, el banco... Bien había podido exigir el pago de la obligación a los codeudores... Efectuado el cual, sin más, quedaría extinguida la obligación para todos los deudores solidarios..."

61 Posición que ha definido la tesis actual y dominante de la Corte tal y como se puede ver en Sentencias de 25 de mayo de 2005 (M.P. Arrubla Paucar, 2005), 29 de septiembre de 2005 (M.P. Arrubla Paucar, 2005), 15 de diciembre de 2008 (M.P. Arrubla Paucar, 2008), 5 de octubre de 2009 (M.P. Arrubla Paucar, 2009), y, 16 de mayo de 2011 (M.P. Díaz Rueda, 2011)

62 En este sentido, la teoría de que legitimación en la causa tiene que ver con la identidad entre el sujeto y la titularidad del derecho se traduce en el riesgo asegurado y el interés que tiene el banco en el momento de celebrar el contrato de seguro. Así, “... en el seguro de vida grupo deudores, tomado por el acreedor sobre la vida de su deudor o grupo de deudores, el interés asegurable lo detenta exclusivamente el acreedor, quien lo contrata para evitar el perjuicio que la muerte del deudor le pueda ocasionar si para entonces no se encuentra satisfecho a cabalidad el crédito... El interés del propio deudor, o de sus eventuales sucesores, son asegurables bajo otra modalidad de contratación en que el mutuario lo toma sobre su propia vida y designa como beneficiario oneroso al mutuante para que, en el evento de su muerte o incapacidad total, la deuda quede extinguida mediante el pago que haga el asegurador y no se transmita entonces a los sucesores ni afecte el patrimonio conyugal. Pero no es éste, insistimos, el interés que se asegura bajo el seguro que es materia de nuestro estudio" (Falta de legitimación en el seguro de vida grupo deudores, 2012) 
ningún sentido, por medio del contrato de seguro vida grupo deudores, al pago subsidiario o solidario de la deuda del asegurado con el banco. Esta última situación puede asegurarse por medio de otros seguros, como por ejemplo el seguro de crédito.

La interpretación de la Corte no tiene en cuenta el principio de relatividad de los contratos en relación con la póliza de vida grupo deudores, debido a que pretende que, por medio de la figura de la subrogación, se vincule contractualmente a la aseguradora al pago. Lo anterior contraría la calidad de tomador y beneficiario oneroso del banco y desconoce el concepto sustancial que tanto la doctrina, como la misma Corte, han establecido para el término "legitimación en la causa"63.

La subrogación es la trasmisión de los derechos del acreedor a un tercero ${ }^{64}$. Bajo esta definición, no es posible sostener que el heredero o cónyuge supérstite son terceros respecto del contrato de mutuo, puesto que la deuda que estos sujetos están pagándole al banco la adquirieron por vía de la sucesión y las obligaciones a cargo de la sociedad conyugal respectivamente. (Falta de legitimación en el seguro de vida grupo deudores, 2012)

Igualmente, la subrogación solo puede predicarse respecto del contrato de seguro porque no se puede transferir el interés asegurable que tiene el banco en el cubrimiento del riesgo de la muerte del deudor. Diferente sería si el interés asegurable estuviera en cabeza del deudor, o asegurado, toda vez que, en este supuesto, dicho interés sí puede transmitirse por vía de los derechos sucesorales y del haber conyugal. Empero, como se ha dicho en varias ocasiones, el seguro vida grupo deudores contratado por el banco tiene como interés asegurable el de la entidad financiera.

63 La doctrina sostiene en materia procesal que: "Nadie podría poner en duda que el no pago de la obligación asegurada afectaría desde un punto de vista eminentemente práctico (utilidad en palabras de Rocco), los intereses de la viuda y de los herederos en las liquidaciones de la sociedad conyugal y de la herencia, pues ese sería un pasivo que gravaría esos patrimonios autónomos. Sin embargo, de este aserto no se puede colegir lo que en ambas sentencias la Corte concluyó, no solo porque al tratarse de legitimaciones extraordinarias se precisaría de la norma que autorizara la legitimación, la cual no existe, como ya se explicó, sino porque esa condición apenas les permitiría intervenir como coadyuvantes (terceros) en el proceso que el mismo banco adelantara contra la aseguradora (art. 71 del Código General del Proceso y art. 52 del Código de Procedimiento Civil).” (Legitimación del cónyuge sobreviviente y de los herederos con ocasión de los contratos de seguros de vida grupo deudores, 2015)

64 Artículo 1668 del C.C. 
En conclusión, si no existe subrogación de los derechos del beneficiario oneroso porque dicha figura no tiene sustento legal o convencional, no existe derecho sustancial, en cabeza del heredero o cónyuge supérstite del asegurado, que lo legitime en la causa para reclamar judicialmente el pago del seguro de vida.

\subsubsection{La responsabilidad extracontractual derivada de la inejecución del seguro de vida grupo deudores}

En el evento en que los herederos y el cónyuge supérstite demandan que la aseguradora pague al banco el valor de la póliza, la legitimación en la causa tiene su origen en el perjuicio que estos pueden sufrir con las conductas del banco y la aseguradora respecto de la inejecución del contrato de seguro vida grupo deudores, siendo procedente la acción de responsabilidad civil extracontractual ${ }^{65}$.

La CSJ ha entendido que los herederos y el cónyuge supérstite, que son terceros respecto al seguro de vida contratado por el banco, tienen a su disposición la acción de responsabilidad civil extracontractual. Así, el principio de relatividad de los contratos tiene límites en la medida que no se puede desconocer la realidad del contrato y sus efectos sobre terceros que pueden verse afectados por su ejecución ${ }^{66}$.

Una tesis concordante con la posición antes expuesta fue sostenida en Concepto 2011013293-002 de 28 de abril de 2011. Allí la SFC precisó al usuario que, en cuanto a la legitimación en la causa de los herederos y el cónyuge supérstite, tales sujetos podían hacer valer sus derechos por medio de la acción de responsabilidad civil extracontractual ${ }^{67}$.

65 Sobre la evolución de la jurisprudencia de la CSJ, la doctrina precisa: "La jurisprudencia de la sala de casación civil de la Corte Suprema de Justicia, en una primera etapa, fundamento la legitimación de los causahabientes del deudor, bajo las normas propias de la subrogación y, posteriormente, ante las críticas que suscitaron esos pronunciamientos, la jurisprudencia se centró en la existencia de un detrimento patrimonial para los causahabientes del deudor y como no tenían carácter de beneficiarios en el contrato de seguro, ese detrimento debía ser reclamado por la vía extracontractual.” (Legitimación de la viuda y de los herederos bajo el seguro de vida grupo deudores, 2013)

66 Resalta la Sentencia de 28 de julio de 2005 que: "La realidad de los contratos no le impide a la viuda del deudor de un crédito hipotecario demandar a la aseguradora para que le pague al banco el seguro de vida que ampara la obligación" [La Corte no casó una sentencia en la que el Tribunal Superior del Distrito de Medellín concedió la acción extracontractual a la viuda de un deudor asegurado. Según los hechos la aseguradora se rehusaba a pagar el seguro porque la entidad financiera no expidió el certificado individual de seguro] (M.P. Trejos Bueno, 2005).

67 La Superintendencia Financiera manifestó en el citado concepto: "No obstante lo expuesto con anterioridad, si la interesada considera perjudicados sus intereses económicos se encuentra en 
La jurisprudencia de la SFC tampoco ha sido extraña a los pronunciamientos de la CSJ. En este sentido, la entidad aceptó la legitimidad en la causa por activa de los herederos del deudor, bajo el sustento de que la relación económica existente entre el asegurado y la deuda los afecta patrimonialmente. La posición de la Superintendencia es similar a los pronunciamientos más recientes de la Corte $^{68}$. Así, la entidad considera que, si bien generalmente se tiene como legitimado para reclamar el seguro al beneficiario oneroso, pueden existir otros intervinientes en el seguro de vida grupo deudores que están legitimados para exigir el cumplimiento del contrato, en razón a que su patrimonio se ve afectado o el beneficiario oneroso ya no tiene esa calidad ${ }^{69}$.

Teniendo en cuenta que la Superintendencia solamente tiene competencias jurisdiccionales en materia contractual respecto de los sujetos vigilados y sus relaciones con el consumidor, le es imposible sostener expresamente que la legitimación en la causa de los herederos proviene de la responsabilidad extracontractual ${ }^{70}$. Si esto fuera así tendría que remitirse el asunto a un Juez de la jurisdicción civil ordinaria.

libertad de adelantar ante las autoridades judiciales, las acciones tendientes a la indemnización por responsabilidad civil extracontractual que con su acción u omisión le hubiere causado el banco.”[En consulta a la Superintendencia Financiera, un usuario formula varias inquietudes relacionadas con la legitimación en causa por activa para efectos de hacer efectiva una póliza de vida grupo deudores con ocasión del fallecimientos de su hijo] (SFC, 2011)

68 A pesar de lo anterior, la Superintendencia aún parece confundir la tesis de la subrogación y la responsabilidad extracontractual como sustento de la legitimación en la causa de los demandantes. Así lo demuestra el siguiente pasaje de la Sentencia de 17 de enero de 2014 donde se afirmó: "No obstante lo anterior, es del caso señalar, que si bien es cierto, en principio, es el beneficiario el legitimado para reclamar de la compañía aseguradora el pago de la prestación asegurada, tal prerrogativa, puede en algunas oportunidades, desplazarse a otros intervinientes del contrato de seguro, por ejemplo, cuando alguno de ellos acredita que la razón por la cual se designó un beneficiario oneroso ha cesado, o que la relación económica que une al asegurado con un determinado bien patrimonial u obligación ahora, le involucra y afecta su patrimonio." [Los herederos de una deudora fallecida, reclamaron ante la Superintendencia el pago del seguro de vida grupo deudores, vinculándose al proceso el banco y la aseguradora] (SFC, 2014)

69 Similar posición fue igualmente sostenida por la Superintendencia Financiera en Sentencia de 14 de febrero de 2014. Radicado: 2013-029122; Sentencia de 22 de mayo de 2014. Radicado: 2013502; Sentencia del 30 de julio de 2014. Radicado:2014-0038; y Sentencia del 23 de enero de 2015. Radicado: 2014-0717.

70 Según el artículo 57 de la Ley 1480 de 2011: "En desarrollo de la facultad jurisdiccional atribuida por esta ley, la Superintendencia Financiera de Colombia podrá conocer de las controversias que surjan entre los consumidores financieros y las entidades vigiladas relacionadas exclusivamente con la ejecución y el cumplimiento de las obligaciones contractuales que asuman con ocasión de la actividad financiera, bursátil, aseguradora y cualquier otra relacionada con el manejo, aprovechamiento inversión de los recursos captados del público". En este sentido, la Ley 1328 de 2009 en su artículo 2 literal d) define al consumidor financiero como "todo cliente, usuario o cliente potencial de las entidades vigiladas". 
Legitimar al heredero o al cónyuge supérstite con base en la idea de que le afectan las acciones del banco y la aseguradora, en relación con el cumplimiento del seguro de vida, muestra una posición concordante con la postura examinada anteriormente de la CSJ. En el fondo la solución al problema jurídico se encuentra en la interpretación del principio de relatividad de los contratos ${ }^{71}$.

Sin embargo, son varias las cuestiones que no están resueltas bajo el entendido de que la legitimación en la causa de los herederos y cónyuge supérstite tenga su sustento en la acción de responsabilidad civil extracontractual.

En primer lugar, los herederos y el cónyuge supérstite deben acreditar la existencia de un daño para que la acción prospere. Así, cabría preguntarse cuál es el perjuicio que sufren los demandantes puesto que las deudas del causante se heredan por causa de la ley de sucesión o, en el caso de la viuda, por motivo de la liquidación de la sociedad conyugal ${ }^{72}$.

En segundo lugar, la tesis no resulta lógica respecto de los derechos de las partes del contrato de seguro, toda vez que el heredero o cónyuge supérstite tendría que probar el daño causado, su nexo causal, y, la culpa del banco o de la aseguradora. Incluso si el Juez encuentra probada la existencia de un daño que fundamente la responsabilidad, la aseguradora pudo haber objetado la reclamación con razones válidas en materia jurídica, haciendo a su vez, que el banco procediera a perseguir el pago de la deuda haciendo efectivas las garantías o cobrándole a los herederos, situación que exoneraría a ambas partes de pago alguno a su cargo, tanto por falta de culpa como de nexo causal con relación al daño.

71 Al respecto la Sentencia de 28 de julio de 2005, mencionada anteriormente, expone claramente la posición de la Corte (M.P. Trejos Bueno, 2005). Igualmente, la doctrina sostiene que el principio general es el de la relatividad de los actos jurídicos y según el cual, no confieren derechos ni imponen obligaciones a cargo de terceros, sin embargo este principio no es absoluto y es así como se reconocen como excepciones, ciertos actos unipersonales que pueden generar derechos para terceros que no han participado en manera alguna en su celebración. (Legitimación de la viuda y de los herederos bajo el seguro de vida grupo deudores, 2013).

72 Tal es la posición de una parte de la doctrina que sostiene: "En todo caso, no podrá entenderse que constituye perjuicio hacer el pago de una obligación, así se trate de una deuda transmitida por causa de muerte de un deudor original, o que por esa causa se disminuya el patrimonio sucesoral." (Falta de legitimación en el seguro de vida grupo deudores, 2012). 
Empero, la tesis de la subrogación de los herederos y cónyuge supérstite en la calidad de beneficiarios no responde satisfactoriamente al problema, debido a que desconoce varias disposiciones legales y el principio de relatividad de los contratos. No obstante, es evidente que esta posición reconoce que el asegurado tiene interés asegurable en el contrato de seguro y de alguna manera reivindica el hecho de que el deudor sea el responsable del pago de la prima, a pesar de que, por disposición legal, sea el tomador quien tiene esta obligación.

En conclusión, la jurisprudencia de la CSJ ha consolidado una posición relativamente sólida, por medio de la cual ha permitido a los herederos y cónyuges sobrevivientes del deudor solicitar a la aseguradora el pago del seguro, ante la inactividad del tomador. En concordancia con lo anterior, la SFC, en el ejercicio de sus facultades jurisdiccionales, presenta una posición similar a la formulada por la Corte, guardando diferencias de carácter teórico porque carece de las competencias legales para conocer de acciones de responsabilidad civil extracontractual.

\subsection{Conclusiones}

Teniendo en cuenta la jurisprudencia de la CSJ y la SFC, en lo relativo a la legitimación de terceros que no son parte en el contrato de seguro, se tiene como conclusión que los herederos y el cónyuge supérstite tienen a su disposición la acción de responsabilidad civil extracontractual como el medio más eficaz para acceder a la jurisdicción y reclamar sus derechos. Los sujetos antes mencionados pueden intentar la reclamación judicial del seguro alegando la subrogación en los derechos del beneficiario oneroso, no obstante, tendrán que verse en la necesidad de sustentar el derecho sustancial que ostentan para tener legitimidad en la causa, situación que puede ser desventajosa para sus pretensiones.

\section{La prescripción de las acciones y derechos en el contrato de seguro, visión jurisprudencial}

La prescripción en lo ateniente con el ejercicio de las acciones y derechos derivados del contrato de seguro, desde la expedición misma del C.Co. ha sido un tema de extenso debate para los tribunales competentes. 
Tales pronunciamientos han centrado su atención en debatir el contenido y alcance del artículo $1081^{73}$ del C.Co. norma que estableció el régimen legal aplicable a la prescripción de las acciones y derechos derivados del contrato de seguro.

Ciertamente, el artículo en mención establece dos clases de prescripción $^{74}$, una ordinaria (subjetiva) y otra extraordinaria (objetiva), la ordinaria será de dos años y empezará a correr desde el momento en que el interesado, haya tenido o debido tener conocimiento del hecho que da base a la acción; la extraordinaria será de cinco años, correrá contra toda clase de personas, y empezará a contarse desde el momento en que nace el respectivo derecho.

El término de prescripción ordinaria corre para todas las personas capaces desde que conocen o debieron conocer el hecho que da base a la acción, no aplica en relación con los incapaces y no corre contra quien no conoció ni debió conocer; la extraordinaria corre sin solución de continuidad desde el nacimiento del derecho siempre que no haya transcurrido la ordinaria ${ }^{75}$.

Ahora bien, es preciso señalar que tales plazos corren simultáneamente y adquiere firmeza jurídica el primero que se configure ${ }^{76}$.

Dicha norma, opera respecto de todas las acciones que pueden impetrarse en razón al contrato de seguro o de las disposiciones que lo rigen. Acciones tales como el pago de la indemnización, la exigencia del pago

73 Artículo 1081 C.Co. "La prescripción de las acciones que se derivan del contrato de seguro o de las disposiciones que lo rigen podrá ser ordinaria o extraordinaria. La prescripción ordinaria será de dos años y empezará a correr desde el momento en que el interesado haya tenido o debido tener conocimiento del hecho que da base a la acción. La prescripción extraordinaria será de cinco años, correrá contra toda clase de personas y empezará a contarse desde el momento en que nace el respectivo derecho. Estos términos no pueden ser modificados por las partes".

74 Las dos clases de prescripción... se diferencian por su naturaleza: subjetiva, la primera, y objetiva, la segunda; por sus destinatarios: quienes siendo legalmente capaces conocieron o debieron conocer el hecho base de la acción, la ordinaria, y todas las personas, incluidos los incapaces, la extraordinaria; por el momento a partir del cual empieza a correr el término de cada una (Corte Suprema de Justicia, 2002).

75 Véase sentencia de la Corte Suprema de Justicia. Sala de Casación Civil del 3 de mayo de 2000 M.P Nicolás Bechara Simancas (Corte Suprema de Justicia, 2000).

76 "Cada uno de los términos de prescripción de las acciones a que da origen el seguro, el de dos años (la ordinaria), el de cinco años (la extraordinaria), corre por su lado y con arreglo a sus presupuestos" (Ossa, 1991). 
de la prima, la devolución de primas no devengadas, la recisión del contrato por nulidad relativa, entre otras.

Sin embargo, en lo que concierne al objeto del presente escrito, nos centraremos en enunciar las posiciones que la SFC, ha señalado en sus fallos en facultades jurisdiccionales, contraponiéndolas con las expuestas por la CSJ respecto del mismo asunto.

Lo anterior con el fin de señalar las concordancias, o disparidades que se presenten entre lo dispuesto por cada Corporación, presentando la opinión que merezca el resultado de este examen comparativo.

En ese sentido, la Delegatura ha conocido controversias en las que, por lo general, la discusión se centra en esclarecer, frente a la exigibilidad de la indemnización, cuál es el hecho que da base a la acción o el momento en el que nace el respectivo derecho; y si ese mismo, sea cual fuere ${ }^{77}$, se encuentra dentro del plazo dispuesto en la legislación comercial para ser objeto de análisis de la Corporación, o si por el contrario, fenecido el plazo, el actor ha perdido la oportunidad de ejercer la acción pretendida.

Por lo anterior, pasaremos a relacionar algunas de las temáticas abordadas por la Delegatura que envuelven en su parte resolutiva la aplicación de la prescripción de las acciones derivadas del contrato de seguro, poniendo de presente los lineamientos que ha sentado dicha Corporación para resolver las controversias que se susciten bajo su competencia.

Para tal fin, en primera medida se analizará el fenómeno de la prescripción desde sus implicaciones sustanciales para, en segunda medida, analizar la institución, desde su perspectiva procesal.

77 El término de una y otra prescripción comienza a correr desde momentos distintos así: ... El de la ordinaria, a partir de cuándo el interesado (y ya se vio quiénes lo son) tuvo conocimiento o razonablemente pudo tenerlo, "del hecho que da base a la acción". Este hecho no es, no puede ser otro, que el siniestro, entendido éste, según el artículo 1072 ibídem, como "la realización del riesgo asegurado", o sea del hecho futuro e incierto de cuya ocurrencia depende el nacimiento de la obligación de indemnizar a cargo del asegurador y correlativamente del derecho del asegurado o beneficiario a cobrar la indemnización ... El de la extraordinaria comienza a correr " contra toda clase de personas ... desde el momento en que nace el respectivo derecho", expresión ésta que sin duda alguna equivale a la que emplea el segundo inciso del artículo que se comenta. El derecho a la indemnización nace paro [sic] el asegurado o para el beneficiario, en su caso, en el momento en que ocurre el hecho futuro e incierto a que estaba suspensivamente condicionado, o lo que es lo mismo, cuando se produce el siniestro. (Corte Suprema de Justicia, 1977). 


\subsection{Implicaciones sustanciales}

\subsubsection{Comentarios con respecto al momento en que se hace exigible la indemnización derivada del contrato de seguro}

Para la Delegatura, por regla general, el siniestro es el hecho que da base a la acción derivaba del contrato de seguro. No obstante, tal circunstancia, a efectos de contabilizar la prescripción puede coincidir con eventos distintos al siniestro, tales como la comunicación a través de la cual el accionante informa a la aseguradora que conoció la existencia de la póliza, la entrega de la póliza de seguro al asegurado, la reclamación ante la aseguradora hecha por el asegurado o beneficiario, o la calificación de pérdida de capacidad laboral, entre otras.

En efecto, en sentencia de diciembre 16 de $2014^{78}$ (Superintendencia Financiera, 2014) la Corporación señaló que, en materia de seguros, el hecho que da base a la acción para efectos de contabilizar la prescripción no se limita al siniestro en sí mismo, aunque éste es el momento más usual, la prescripción se contabilizará siempre desde que el asegurado conoció o debió haber conocido el hecho que le permite reclamar cualquier situación derivada del contrato de seguro.

Así las cosas, el siniestro es uno de los eventos que permite al asegurado exigir a la aseguradora una reclamación, pero no el único.

A modo de ejemplo, en sentencia de diciembre 10 de $2015^{79}$ (Superintendencia Financiera, 2015) la Delegatura señaló que, para el caso bajo estudio, el hecho que dio base a la acción coincidía con la fecha del

78 Acción instaurada en procura que se declare la aseguradora contractualmente responsable de indemnizar los perjuicios ocasionados por la expedición de la póliza "Protección En Cáncer", que aquel señala no asintió en su suscripción y cuya expedición atribuye a una falta de asesoría en la venta. El demandante fue contactado vía telefónica con el fin de comercializar la póliza "Renta Por Hospitalización" la cual incluía el amparo de cáncer, sin embargo según la demanda, en dicha llamada nunca se indicó que tal amparo era independiente a la de renta por hospitalización, siendo una póliza completamente distinta. No obstante lo anterior el condicionado de cada póliza fue entregado y por ende el asegurado debía conocer las condiciones de los contratos.

79 Acción instaurada en procura de que se declare a la aseguradora contractualmente responsable de la indemnización establecida en la póliza por los hechos ocurridos en la vivienda de la asegurada en la ciudad de Barranquilla, el siniestro fue notificado a la aseguradora a través de unos informes que daban noticia del evento. 
informe preliminar del evento que se pretendía dilucidar como siniestro. Sin embargo, incluso tomando como fecha de partida la solicitud de documentos para atender la reclamación por parte de la aseguradora demandada, se evidenciaba que la acción se había impetrado por fuera del término legal consagrado en el artículo 1081 del C.Co.

A su vez, en sentencia de noviembre 26 de $2015^{80}$ (Superintendencia Financiera, 2015) la Superintendencia indicó que el hecho que da base a la acción puede coincidir con el conocimiento sobre la calificación de la pérdida de capacidad laboral, pues resulta indiscutible que para ese momento el actor tiene pleno y total conocimiento de los hechos que determinaron su pérdida de capacidad laboral, luego no resulta necesario hacer otro ejercicio diferente que contar los dos años para efecto de determinar que al momento en que se presentara la demanda, ya había excedido el término de dos años que prevé el artículo 1081 del C.Co. para iniciar las acciones judiciales pertinentes.

Por su parte, la CSJ en diversos fallos estableció que, a efecto de la prescripción ordinaria de las acciones derivadas del contrato de seguro, no basta el acaecimiento del hecho que da base a la acción, sino que es necesario que el titular del interés haya conocido o debido conocer del mismo.

Lo anterior, bajo el entendido que para la Corte la prescripción ordinaria correrá desde que se haya producido el conocimiento real o presunto del hecho que da base a la acción, sea éste el siniestro, el impago de la prima, el incumplimiento de la garantía, la floración de la reticencia o de la inexactitud en la declaración del estado de riesgo, etc ${ }^{81}$.

Adicionalmente, es importante traer a colación que, para la Corte, existen otras excepciones a la regla con base en la cual, el siniestro es el hecho que da base a la acción.

Ciertamente, en el caso del seguro por lucro cesante, el riesgo asegurado no es exactamente un hecho aislado que condiciona la obligación de la

80 Acción instaurada en procura que se declare la aseguradora contractualmente responsable de reconocer la suma asegurada por concepto del amparo de incapacidad total y permanente de una póliza de vida grupal.

81 "Véase sentencia del 19 de febrero de 2002 M.P Nicolás Bechara Simancas. (Corte Suprema de Justicia, 2002). 
aseguradora, (léase incendio, terremoto, rayo en aparato electrónico, entre otros), pues bajo este escenario el riesgo corresponde al período de pérdidas o de disminución real de los ingresos que se presente durante el ciclo de rehabilitación de la actividad del asegurado una vez acaecido el siniestro.

En ese entendido, el siniestro tiene dos implicaciones, ser la fuente de interrupción del negocio y el nacimiento de la pérdida operacional del asegurado. En ese sentido, si bien la obligación nació con la materialización del daño por lucro cesante, su exigibilidad queda diferida en el tiempo hasta la readaptación del negocio asegurado, como si no hubiese ocurrido el siniestro.

En otras palabras, a partir de la ocurrencia del riesgo, el daño por lucro cesante y su exigibilidad se halla en estado potencial, de latencia, de tal modo que la obligación correlativa del asegurador aún no es exigible sino que pende del período de readaptación ${ }^{82}$.

Otro caso que debe mencionarse en este acápite se relaciona con la regla establecida por la CSJ, según la cual, para computar el término de prescripción ordinaria de las acciones derivadas del contrato de seguro, en pólizas que amparen el lucro cesante por riesgos catastróficos, el conocimiento real o presunto del siniestro se estructura no solo cuando ocurre un hecho notorio como un terremoto sino cuando se precisan los efectos nocivos que dicho fenómeno natural produce en el negocio amparado.

En ese sentido, no basta con la concurrencia del evento catastrófico para que se configure el hecho que da base a la acción, sino que para su exigibilidad se hace necesario dilucidar los efectos nocivos que el mismo produzca ${ }^{83}$.

82 En últimas, así se tratará en forma hipotética exclusivamente de una condición, conforme al artículo 1542 del Código Civil, no puede exigirse el cumplimiento de la obligación condicional sino verificada la condición totalmente. De este modo, en consonancia con la naturaleza del riesgo, surgen dos categorías o elementos diferenciables del propio riesgo (i) la ocurrencia del hecho condicionante (incendio), y (ii) el daño asegurado. (Corte Suprema de Justicia, 2016).

83 El quid del asunto, por lo tanto, se reduce a establecer cuál de esas circunstancias fácticas, debidamente demostradas, se subsume en la hipótesis del artículo 1081 del Código de Comercio, esto es, si para computar el término de prescripción ordinaria de las acciones derivadas del contrato de seguro, el conocimiento real o presunto del siniestro, tenía que darse por superado, una vez ocurrido el hecho notorio del terremoto o al "conocer" el demandante a "ciencia cierta" la pérdida total del edificio... Con ese propósito, pertinente resulta dejar bien claro que el fenómeno natural, por sí sólo, sin daños, pues no siempre los causa, carece de connotación indemnizatoria, razón por la cual, necesariamente, debe asociarse con los efectos nocivos que produjo. (Corte Suprema de Justicia, 2010). 
Adicionalmente, la providencia en comento establece que es posible suspender el término de prescripción de la acción derivada del contrato seguro cuando el comportamiento de la aseguradora estuviese impregnado de la mala fe o fuese abusivo. Aclaramos que tal pronunciamiento no tuvo incidencia en la parte resolutiva de la sentencia.

Visto esto, es posible encontrar un punto de contacto en las tesis de ambas corporaciones. Esto es: el siniestro es uno de los eventos que permite al asegurado exigir a la aseguradora una reclamación, pero no el único.

\subsubsection{Conocimiento de la póliza y sus condiciones}

En sentencia de diciembre 19 de $2014^{84}$ (Superintendencia Financiera, 2014) la Superintendencia señaló que la entrega de la póliza de seguro al asegurado supone que este último conoce las reglas propias del contrato que suscribió y, por ende, las acciones que pretenda iniciar corren a partir del momento mismo en que ésta se haya materializado.

Por lo tanto, cualquier acción pretendida contra la aseguradora empieza a correr desde el momento de la entrega de la póliza, y no podrá alegarse el desconocimiento de las condiciones del contrato con el fin de que se aplique otro término de prescripción o que el mismo empiece a correr en el momento en que el asegurado conoció la condición objeto del litigio.

Por su parte para la CSJ, compartiendo la posición de la Delegatura considera que el desconocimiento de las condiciones del contrato de seguro no obsta para que se aplique un término de prescripción diferente al ordinario ${ }^{85}$, es decir que, para el máximo tribunal, no es posible pretender que se aplique el término de prescripción extraordinario, cuando se

84 Se presenta demanda en procura que se declare a la aseguradora contractualmente responsable del incumplimiento del deber de información respecto de unos seguros de vida, y en consecuencia se condene al reembolso de la prima.

85 Delimitados como se encuentran los alcances del artículo 1081 del Código de Comercio, por la percepción que tenga el interesado del suceso que lo legitima para obrar y la aptitud legal para ser sujeto de los derechos que invoca, no goza de validez la alegación del censor en el sentido de que el desconocimiento de la existencia del contrato de seguro, por parte del asegurado, se constituye en un nuevo motivo para estudiar su situación al amparo de la prescripción extraordinaria...Admitir la argumentación aducida por el recurrente en el sentido de que la ignorancia de la existencia de la póliza encasilla en la modalidad extintiva extraordinaria la prosperidad del pleito, significaría una modificación normativa, que prohíbe precisamente la naturaleza de orden público que le confiere la ley a la prescripción. (Corte Suprema de Justicia, 2013) 
alega haber conocido la condición en una época distinta a la suscripción del contrato ${ }^{86}$.

Por lo anterior, nuevamente encontramos paridad de posiciones entre los tribunales analizados.

\subsubsection{Prescripción de la acción de nulidad del contrato de seguro basada en la reticencia o inexactitud del asegurado}

Como es sabido, la rescisión por nulidad relativa del contrato de seguro también se somete al régimen de prescripción establecido en el artículo 1081 del C.Co, pudiéndose alegar tanto por vía de acción como de excepción.

Refiriéndose a la posibilidad de plantearse tal fundamento tanto por vía como de acción como de excepción la $\mathrm{CSJ}^{87}$ ha señalado que efectivamente la acción de nulidad del contrato de seguro basada en la reticencia o inexactitud del asegurado puede prescribir, contraviniendo la máxima según la cual la acción es temporal al paso que la excepción perpetua, fundamentado en dos razones: La primera basada en que la legislación colombiana ha adoptado el sistema de saneamiento de nulidades, que es la sanción prevista para la reticencia e inexactitud, y la segunda, relacionada con el carácter definitivo que se asigna a la prescripción dentro del contrato de seguro.

Así las cosas, la prescripción procede frente a la excepción de reticencia e inexactitud, y tal prescripción puede ser la ordinaria o la extraordinaria, aplicándose tal como lo determina el C.Co. Esto es, dos años a partir de que conoció o debió haber conocido el asegurador, o cinco años a partir del momento en que nace la reticencia o inexactitud, lo cual en sede contractual, se traduce al momento de perfeccionamiento del contrato, lo anterior en aplicación del artículo 1750 del C.Co, norma que establece que la prescripción de la acción de nulidad en los casos de error y dolo comienza a contarse desde la fecha de suscripción del contrato.

86 (Corte Suprema de Justicia, 2013)

87 Corte Suprema de Justicia. Sala de Casación Civil. Sentencia de 3 de mayo de 2000. M.P. Nicolás Bechara Simancas. 
En otras palabras, la ley comercial estableció que, trascurridos cinco años de vigencia del contrato de seguro, cualquier inexactitud o reticencia en la declaración del estado del riesgo se sanea por efecto de la prescripción de la acción de nulidad.

La aplicación de dicho precepto legal ha sido ampliamente criticada por la doctrina colombiana. Al respecto se ha pronunciado el tratadista Andrés Ordoñez ${ }^{88}$, señalando que la aplicación de esta norma en caso de la declaratoria de nulidad relativa del contrato de seguro por reticencia o inexactitud, puede generar circunstancias propiciatorias del fraude contra las aseguradoras. En la misma línea, Jorge Eduardo Narváez ${ }^{89}$ considera inaceptable que un término de prescripción pueda comenzar a contarse sin que el interesado conozca la existencia del hecho en que puede fincar su demanda, para el tratadista es posible que tal situación se deba a una inconveniente acomodación de la ley francesa ${ }^{90}$ a la colombiana.

Ahora bien, analizada la posición de la Corte y los comentarios que al respecto ha esbozado la doctrina colombiana, pasaremos a señalar la posición adoptada por la SFC en desarrollo de sus facultades jurisdiccionales.

Es así como en sentencia del 27 de Abril del 2017 (Superintendencia Financiera 2017) ${ }^{91}$ después de una extensa remisión a la providencia de la CSJ arriba señalada, decide que para el momento de en qué se presentó la contestación de la demanda, oportunidad procesal en la que se formuló la excepción de "ausencia de prescripción de la acción de nulidad relativa", había trascurrido un término superior a cinco años desde que se suscribió el contrato, por lo que, en dicha oportunidad, se declaró prescrita la acción que pretende la declaratoria de nulidad del contrato de seguro basada en la reticencia o inexactitud del asegurado.

88 El Tratamiento Civil De La Mala Fe Del Asegurado En El Contrato De Seguro (Ordoñez, 2005).

89 José Eduardo Narváez. El Contrato de Seguro en el Sector Financiero. Ediciones Librería del Profesional. Primera Edición. Bogotá 2002. Página 348 y siguientes (Narváez, 2002).

90 José Eduardo Narváez. El Contrato de Seguro en el Sector Financiero. Ediciones Librería del Profesional. Primera Edición. Bogotá 2002. Página 348 y siguientes. (Narváez, 2002).

91 En este caso se demanda el pago de la indemnización derivada del contrato de seguro y adicionalmente se pretenden la declaratoria de la prescripción de la acción que pretenden la declaratoria de nulidad relativa del contrato por reticencias e inexactitudes, la aseguradora se opuso a las pretensiones a través de la excepción que denominó prescripción o caducidad de la acción de protección al consumidor. 
En consecuencia, tanto la CSJ como la SFC entienden que la declaratoria de nulidad del contrato de seguro, alegada bien sea a través de acción o excepción, puede prescribir bien sea bajo el término ordinario como por el extraordinario.

\subsubsection{En cuanto a la interrupción de la prescripción}

La interrupción de la prescripción puede ser natural o civil (Artículo 2539 C.C. $)^{92}$, de tal forma que verificada alguna, se pierde el tiempo de prescripción transcurrido y que volverá a comenzar a correr una vez cese la causa que motiva la interrupción.

Adicionalmente, el artículo $94^{93}$ del C.G.P dispuso una modalidad adicional para la interrupción civil de la prescripción, por lo que haremos una breve mención sobre el alcance del inciso final de éste artículo y los requisitos del requerimiento escrito para que tenga la virtualidad de interrumpir la prescripción.

Es preciso señalar que en materia de seguros no se prevé que el aviso de siniestro o la presentación de la reclamación interrumpan la prescripción, motivo por el cual se debe acudir a las normas generales del derecho civil para efectos de establecer los preceptos bajo los cuales procedería la interrupción de la prescripción.

De acuerdo con el tratadista Hernán Fabio López, el requerimiento escrito a que hace mención el inciso final del artículo 94 del C.G.P para que produzca el efecto de interrumpir la prescripción, "debe ser preciso, concreto e identificar claramente la obligación cuyo pago se solicita”. Y agrega entonces que "comunicaciones de contenido general dirigidas a un deudor no tienen esas connotaciones, como tampoco la puede tener otras que no hacen referencia al punto especifico de obtener el pago. ". (López, 2013)

92 El artículo 2539 del C.C dispone que la prescripción puede interrumpirse naturalmente por el hecho de reconocer el deudor la obligación bien sea de forma tácita o expresa o civilmente por la demanda judicial.

93 Artículo 94. Interrupción de la prescripción, inoperancia de la caducidad y constitución en mora. (...) El término de prescripción también se interrumpe por el requerimiento escrito realizado al deudor directamente por el acreedor. Este requerimiento solo podrá hacerse por una vez. 
En ese sentido, para que exista requerimiento, que produzca el efecto de interrumpir la prescripción, debe exigirse o solicitarse el pago de la obligación, indicando con claridad y precisión la obligación de que se trata. Cuestión que debe tener lugar por escrito para que se produzcan los efectos previstos por la norma. Así no producirán el efecto de la interrupción las peticiones o requerimientos verbales.

En esa medida, cartas o comunicaciones en las que se incluyan únicamente expresiones como que éstas son un requerimiento para el pago o el requerimiento del artículo 94 del C.G.P, sin que en realidad exijan con precisión la obligación de pago que supuestamente se debe, en nuestra opinión, no cumplirían los requisitos necesarios para interrumpir la prescripción.

Por otra parte, es importante tener en cuenta que el artículo 94 del C.G.P deja claro que “(...) este requerimiento solo podrá hacerse una vez (...)”, lo que a nuestro juicio no significa que el acreedor solo pueda exigir una única vez el pago por parte del deudor. Lo que ello significa es que los efectos de la interrupción solo se producirán con el primer requerimiento escrito.

Descendiendo en el terreno del derecho de seguros, debe decirse que es distinto el requerimiento de que trata el artículo 94 del C.G.P, del aviso de siniestro, así como de la reclamación de que trata el artículo 1077 del Código de Comercio, sin perjuicio de que eventualmente una única comunicación pueda producir tanto los efectos previstos en la norma procedimental como los efectos previstos en las normas sustanciales.

En efecto, en materia de seguros, el tratadista Hernán Fabio López, de manera ilustrativa ha manifestado que "por ejemplo el aviso de siniestro cuando se trata de una obligación a cargo de la aseguradora no conlleva las características de requerimiento para el pago, pero sin duda si lo tiene la presentación de la reclamación de que trata el art. 1077 del C. de Co. ${ }^{\text {994. }}$

Por lo anterior, un aviso de siniestro realmente no contiene un requerimiento para el pago, en estricto sentido, no es más que la información que

94 Ibídem. 
se le da a la aseguradora sobre la materialización del riesgo amparado, en él no se reclama o exige el pago de la obligación indemnizatoria que surge del seguro y por ende, no cumple con las previsiones del artículo 94 del C.G.P.

Ahora bien, nada obsta para que una comunicación pueda contener al tiempo un aviso de siniestro y por otra parte un requerimiento para el pago, caso en el cual, con ella se generarían los efectos previstos en las normas sustanciales para el aviso y en las normas procesales para el requerimiento. Así, frente a semejante documento, la aseguradora no podría descontar los perjuicios derivados de la falta de aviso oportuno, y vería interrumpido el término prescriptivo de la acción del asegurado o beneficiario.

En punto de la reclamación, estamos de acuerdo en que ella es un requerimiento, por lo que con la misma se producirá el efecto de interrupción del artículo 94 del C.G.P. Ahora bien, para que exista requerimiento no es necesario que se cumpla con los requisitos del artículo 1077 del C.Co, es decir, que se pruebe la ocurrencia del siniestro y la cuantía de la pérdida.

Así, si una reclamación cumple con los requisitos del artículo 1077 del C.Co., y claramente se solicita el pago de la obligación indemnizatoria, se producirán los efectos de interrupción de la prescripción y además el de que empiece a contarse el término que la aseguradora tiene para pagar o para objetar la reclamación.

Si la reclamación contiene un requerimiento de pago, pero no se acredita la ocurrencia del siniestro y la cuantía de la pérdida, se interrumpirá la prescripción, pero no se producirán los demás efectos propios de una reclamación. Y es que no debe perderse de vista que el artículo 94 del C.G.P en modo alguno exige que se acredite de alguna manera la existencia de la obligación; basta con la exigencia del pago, mediante escrito, identificando la obligación correspondiente.

Al respecto la Dirección Jurídica de la SFC en Concepto del 20 de octubre de 2014 (Superintendencia Financiera, 2014), señaló que esta modalidad general de interrupción de la prescripción introducida por el C.G.P, también aplica a las acciones derivadas del contrato de seguro en 
los casos en los que se consoliden las condiciones de acreedor y deudor de las partes intervinientes en el negocio asegurador, entendiendo por estos la aseguradora, el tomador, el asegurado o el beneficiario.

Bajo la misma línea argumentativa en el laudo arbitral del Instituto de Seguros Sociales - ISS (en Liquidación) vs. La Previsora S.A. Compañía de Seguros, se estableció que "para que se satisfagan las exigencias de la norma procesal, es preciso que ese requerimiento sea formulado por escrito por el acreedor respecto de su deudor, lo que significa frente al contrato de seguro, que esto ocurriría cuando el asegurado o beneficiario formule la reclamación a la aseguradora que cumpla con las exigencias del artículo $1077 . .$. es decir, donde se acredite la materialización del siniestro y su cuantía y, para eludir, interpretaciones dispares, sería deseable que manifestara expresamente que pretende interrumpir el decurso prescriptivo, en los términos del artículo 94 del Código General del Proceso, habida cuenta que la disposición sólo permite hacer uso de ese beneficio por una sola vez."

Una vez puesto de presente el régimen legal aplicable a la interrupción de la prescripción del contrato de seguro, pasaremos a exponer el uso que de la institución ha hecho la Delegatura para funciones jurisdiccionales de la SFC.

En primer lugar, con respecto a la interrupción civil consignada en el artículo 94 del C.G.P, en sentencia del 27 de Abril del 2017 (Superintendencia Financiera, 2017) ${ }^{95}$ la Delegatura señaló que la objeción presentada por la aseguradora no tiene la virtualidad de interrumpir la prescripción derivada del contrato de seguro, por no existir, bajo lo consignado en la objeción una relación entre acreedor y deudor. Decisión que se acopla con los lineamientos anteriormente descritos.

Por su parte, la CSJ refiriéndose al artículo 94 del CGP, en sentencia del 18 de diciembre $2013^{96}$ (Corte Suprema Justicia, 2013), estableció

95 Se exceptúa que la objeción presentada por la aseguradora tiene la virtualidad de interrumpir el término de prescripción de la acción encaminada a la declaratoria de la nulidad del contrato de seguro por reticencia o inexactitud.

96 Pretenden los demandantes se declare la rescisión por lesión enorme de la compraventa de los derechos de posesión de un predio rural suscrita con la sociedad demandada. Agotada la primera instancia el a quo 
que en el armónico entendimiento del artículo 21 de la Ley 640 de 2001, no es posible permite deducir que el reclamo conciliatorio ostente la posibilidad de interrumpir civilmente prescripción y caducidad, pues, de haber sido así, se requería un expreso e inequívoco señalamiento del legislador en ese sentido.

En segundo lugar, con respecto a la interrupción natural de la prescripción en el contrato de seguro, en sentencia del 29 de febrero de $2016^{97}$ (Superintendencia Financiera, 2016) la SFC declara la prescripción de la acción para el pago de la indemnización en el contrato de seguro. No obstante, de los hechos de la demanda se desprende que operó la interrupción natural de la prescripción por reconocimiento de la deuda, evento que se verificó por parte de la aseguradora al efectuar el pago del saldo insoluto del crédito amparado bajo la póliza vida grupo deudores, razón por la cual el término inició nuevamente su conteo.

En el mismo sentido la CSJ ha dado aplicación al precepto legal (Corte Suprema de Justicia,2006) ${ }^{98}$ en donde encontró acreditada la interrupción del término de prescripción en forma natural, ante el reconocimiento tácito que de la obligación surgiera del conjunto de circunstancias que obran en el proceso, precisando que para que se configure este tipo de reconocimiento basta que un hecho del deudor implique inequívocamente la confesión de la existencia del derecho del acreedor: así, el pago de una cantidad a cuenta o

declaró probada la prescripción alegada y terminó el proceso, decisión que fue confirmada por el ad quem al considerar que entre la celebración de la compraventa y la interposición de la demanda transcurrieron más de 4 años, por tanto la acción rescisoria estaba prescrita. La demandante elevó recurso extraordinario con base en la causal primera de casación, acusando la sentencia de violar recta del artículo 21 de la Ley 640 de 2001, por interpretación errónea. La Corte no casó la sentencia por no encontrar acreditados los argumentos de la censura. (Corte Suprema de Justicia Sala de Casación Civil, 2013)

97 Acción en la que se pretende se condene a la aseguradora a devolver las cuotas pagadas de un crédito y reconocer una indemnización por daños y perjuicios al actor. Lo anterior atendiendo a que suscribió una póliza vida grupo deudores y al solicitar la afectación del amparo de ITP el mismo fue objetado. Sin embargo, la aseguradora reconoció a título de pago comercial el valor del saldo insoluto del crédito.

98 Se pretende la responsabilidad derivada del incumplimiento de la compañía aseguradora ante el incumplimiento de los contratos de reaseguro de vida educativo y de vida y accidentes de los empleados de la Caja de Crédito Agrario, Industrial y Minero, en cuanto que a su liquidación, no pagó la participación que por utilidades, comisiones y siniestros que se pactó. La sentencia de segunda instancia confirmó la desestimatoria de las pretensiones proferida por el a quo al encontrar acreditada la prescripción de la acción. En este caso la Corte casó el fallo, en particular por yerros de apreciación probatoria en el análisis de la interrupción natural de la prescripción y en sentencia sustitutiva subsecuentemente revocó la sentencia de primer grado, para en su lugar acceder a las súplicas de la demanda. En igual sentido falló la CSJ en sentencia del Civil de 7 de noviembre de 1977. 
de los intereses de la deuda, la solicitud de un plazo, la constitución de una garantía, las entrevistas preliminares con el acreedor para tratar del importe de la obligación, un convenio celebrado entre el deudor y un tercero con vista al pago del acreedor.

Visto esto, es posible encontrar un punto de contacto en las tesis de ambas corporaciones. Esto es: la interrupción natural de la prescripción en el contrato de seguro se da con el reconocimiento de la deuda que haga la aseguradora, evento en el cual, vuelve a iniciar el conteo del término prescriptivo.

\subsection{Implicaciones procesales}

\subsection{1. ¿Caducidad o prescripción de la acción de protección al consumidor?}

Al respecto, ponemos de presente la discusión que ha suscitado la aplicación bien sea de un término de prescripción o de caducidad para la acción de protección al consumidor de que trata el artículo 58 la Ley 1480 de $2011^{99}$, esto de acuerdo con la reciente posición adoptada por la Superintendencia Financiera basada en una providencia dictada por el Tribunal Superior del Distrito de Bogotá ${ }^{100}$.

En principio, dentro del ejercicio de las facultades jurisdiccionales de la SFC se estableció que el término de un año contando a partir de la terminación del contrato objeto de la controversia sería el plazo para que caducara la posibilidad de demandar ante dicha Corporación.

No obstante, con base en la providencia del 21 de enero de 2016, esbozada por el Tribunal Superior del Distrito Judicial de Bogotá, Ma-

99 De conformidad con el numeral 3 del artículo 58 de la Ley 1480 del año 2011, las demandas en ejercicio de la acción de protección al consumidor deben presentarse a más tardar dentro del año siguiente a la terminación del contrato. En el caso de seguros de grupo, sin que las infracciones respecto de una de las personas o intereses afecte a los demás miembros del grupo, el citado término se contará desde la terminación de la cobertura individual conforme al certificado a éstos suministrado, a pesar que la póliza colectiva continúe vigente. (Superintendencia Financiera de Colombia, 2017)

100 Aclaramos que si bien, los términos bajo los que se finca el presente estudio, se limitan al análisis de la posición de la Superintendencia y de la Corte Suprema de Justicia como máximo órgano de la jurisdicción ordinaria, encontramos especial relevancia en la discusión planteada por el Tribunal Superior del Distrito y por ende, consideramos necesario traerlo a colación. 
gistrada Sustanciadora la Doctora, Julia María Botero Larrarte, la SFC recogió su posición en cuanto a la aplicación de un término de caducidad para la interposición de la acción de protección al consumidor, entendiendo que la acción de protección al consumidor adolece de prescripción y no de caducidad, lo que implica que únicamente opera a petición de parte.

Lo anterior, bajo el entendido que, en aplicación del principio de legalidad, la jurisprudencia, indica dos reglas a seguir para poder establecer cuándo un término legal puede entenderse como de caducidad, a saber (i) cuando la ley así lo indica; (ii) cuando el legislador consagra un lapso para ejercer determinada acción, caso en el cual por vía jurisprudencial se ha entendido como de caducidad ${ }^{101}$.

Sin embargo, el segundo inciso del numeral sexto del artículo 58 de la Ley 1480 de 2011 establece que: "Si transcurridos dos meses desde la interposición de la demanda, y habiéndose realizado las gestiones pertinentes, no es posible su individualización y vinculación, se archivará el proceso, sin perjuicio de que el demandante pueda presentar, antes de que opere la prescripción de la acción, una nueva demanda con los requisitos establecidos en la presente ley y además deberá contener información nueva sobre la identidad del productor y/o expendedor".

Razón por la cual, a la luz de las reglas mencionadas con anterioridad el término aplicable para la acción de protección al consumidor es el de prescripción por existir mención legal que así lo dispone.

\subsection{2. ¿La aplicación del artículo 1081 del código de comercio se vio afectada en virtud de la entrada en vigencia de la ley 1480 del año 2011?}

La Delegatura para funciones jurisdiccionales de la SFC, dentro de los fallos en los que involucran la aplicación del fenómeno de la prescripción, por regla general, inician su argumentación aclarando que cuando la Ley 1480 de 2011 consagró un límite temporal para el ejercicio de la acción de

101 Ver sentencia del 16 de agosto de 1972 (Corte Suprema de Justicia, 2012) y sentencia del 19 de noviembre de 1976. (Corte Suprema de Justicia, 1976) 
protección al consumidor, en ningún caso revocó, interrumpió, suspendió o modificó el régimen legal establecido en el Código de Comercio para la prescripción de las acciones y derechos derivados del contrato de seguro. Lo anterior, puede evidenciarse en la sentencia del 10 de diciembre de 2015 (Superintendencia Financiera de Colombia, 2015) ${ }^{102}$.

\subsection{Conclusiones}

Puesto de presente el panorama con respecto a lo resuelto por la Delegatura para Funciones Jurisdiccionales de la SFC y la posición que al respecto ha merecido la opinión de la CSJ en pronunciamientos similares, es posible concluir que no existen diferencias sustanciales en cuanto a la posición de la Corte Suprema de Justicia y la Superintendencia Financiera de Colombia en relación con la aplicación de lo dispuesto en el artículo 1081 del Código de Comercio.

\section{La libertad probatoria en el marco del contrato de seguro}

Tanto la jurisprudencia de la CSJ como de la SFC han sido unánimes en torno al alcance de la carga probatoria prevista en el artículo $1.077 \mathrm{del}$ C.Co. que le asiste, de un lado, a la parte asegurada [tomador, asegurado o beneficiario] de probar la existencia del siniestro y la cuantía de la pérdida reclamada y, por otro, al Asegurador de acreditar los hechos o circunstancias excluyentes de su responsabilidad.

En ese sentido, en lo que respecta a la carga que le asiste a la parte asegurada, ha precisado en forma tajante que la misma se gobierna bajo el principio de 'libertad probatoria', por consiguiente, el Asegurador no le puede exigir acreditar la ocurrencia del siniestro o su cuantía a través de determinada prueba, toda vez que a juicio de la Corte, es admisible "todo medio probatorio lícito e idóneo, conducente y eficaz y con aptitud para suministrar certeza a propósito [...] incluso admite la relevancia

102 Se trata de la reclamación del pago de la indemnización resultante de un contrato de seguro de incendio para deudores hipotecarios cuyo amparo básico estaba orientado a reconocer las pérdidas ocurridas a los bienes asegurados hasta concurrencia del valor comercial de la parte destructible del inmueble. La Delegatura declara la prescripción ordinaria del contrato teniendo como hecho que da base la acción el siniestro, y hecho el conteo del término de prescripción desde esa fecha el mismo había fenecido. 
jurídica del dato electrónico no sólo respecto del comercio y la contratación sino en materia probatoria (Ley 527 de 1999, arts. 95 ss. de la Ley 270 de 1996) $)^{103}$.

A modo de ejemplo, valga anotar que la SFC, ha señalado que tratándose de pólizas de terrorismo (amparos relativos a huelgas, asonadas, amotinamientos, conmociones civiles y/o terrorismo) no corresponde al asegurado demostrar cuáles eran las motivaciones de los intervinientes en los hechos que dieron origen al siniestro, para identificar si sus acciones se enmarcan dentro de los amparos de la póliza, por lo tanto, concluyó que era válida la prueba de la ocurrencia del siniestro a través de las publicaciones periodísticas son susceptibles de ser apreciadas como pruebas, siempre y cuando guarden conexidad y coincidencia con los restantes elementos probatorios que obran en el expediente ${ }^{104}$.

En otra oportunidad, la SFC denegó las pretensiones de la demanda orientada a hacer efectivo el amparo de pérdida por 'hurto agravado' en el contexto de una póliza de equipo móvil, en la medida en que la demandante no acreditó la ocurrencia del siniestro en los términos en que fue delimitado el amparo, por cuanto de la narración de los hechos que sustentaron su reclamo, se concluyó que se fundó en circunstancias que no eran objeto de cobertura ${ }^{105}$.

En el marco de un seguro de desempleo la SFC desestimó las pretensiones del asegurado, toda vez que si bien la Aseguradora pagó la indemnización dos de las cuotas de la acreencia a favor del Banco acreedor, no obstante, el deudor hipotecario asegurado tuvo una vinculación laboral al tiempo que declaraba que estaba en situación de desempleo -hecho declarado confeso por la inasistencia del demandante a la audiencia-, razón por la cual, fueron desestimadas las pretensiones del actor y, así mismo, se produjo la pérdida del derecho a la indemnización, pese a no existir mala fe del asegurado ${ }^{106}$.

103 Corte Suprema de Justicia. Sentencias de Casación Civil de fechas: 02 de febrero de 2.001 M.P. Carlos Ignacio Jaramillo Exp. 5670, y 14 de junio de 2.009 M.P. Pedro Octavio Munar Cadena Exp. 54001 310320000023501.

104 Superintendencia Financiera de Colombia. Sentencia del 13 de diciembre de 2013. No. 2013029267 Expediente/Radicado: 2013-0130.

105 Superintendencia Financiera de Colombia. Sentencia del 13 de marzo de 2015. No. 2014073295 Expediente/Radicado: 2014-0846.

106 Superintendencia Financiera de Colombia. Sentencia del 27 de marzo de 2015 No. 2014075909 Expediente/Radicado: 2014-0881 
En otra ocasión, la SFC accedió a las pretensiones de la parte actora fincadas en torno a la efectividad del amparo de Incapacidad Total y Permanente previsto en una Póliza Vida Grupo Deudores cuyos asegurados eran docentes adscritos al Magisterio, pese a que a la objeción de la aseguradora estaba fincada en torno a la no acreditación del estado de invalidez a través de los mecanismos establecidos por la Ley 100 de 1993 para acreditar dicho estado (EPS, ARL, Juntas de Calificación).

En esta oportunidad, la SFC estableció que no le era dable a la Compañía desconocer el régimen especial al cual se hallan sometidos los docentes a quienes se encontraban dirigidas las coberturas de la Póliza $\mathrm{y}$, en consecuencia, restarle efectos al dictamen o diagnóstico allegado por la parte actora ${ }^{107}$.

Como puede apreciarse, esta línea jurisprudencial de la SFC se halla en concordancia con las pautas de la CSJ, si se tiene presente que ésta última Corporación, ha establecido la ineficacia de las cláusulas que exigen la prueba de la ocurrencia del siniestro mediante una sentencia judicial ${ }^{108}$.

\section{BIBLIOGRAFÍA}

2009. Laudo Arbitral. s.l. : Cámara de Comercio de Bogotá, 15 de Diciembre de 2009.

Consejo de Estado, Sala de lo Contencioso Administrativo, Sentencia de 28 de febrero de 2017, Exp. 2013-00094-01(52844), M.P. Carlos Alberto Zambrano Barrera.

Corte Constitucional, Sala Séptima de Revisión, Sentencia de tutela de 16 de mayo de 2016, Exp. T-240/16, M.P. Jorge Ignacio Pretelt Chaljub.

Corte Constitucional, Sentencia C-232, M.P. Jorge Arango Mejía.

Corte Constitucional, Sentencia C-269 de 1999, M.P. Martha Victoria Sachica de Moncaleano.

Corte Constitucional, Sentencia C-844/10, M.P. María Victoria Calle Correa.

Corte Constitucional, Sentencia T-153, M.P. Mauricio Gonzalez Cuervo.

107 Superintendencia Financiera de Colombia. Sentencia del 06 de mayo de 2015. No. 2014-0917. Expediente/Radicado: 2014078462

108 Véase al respecto Casación Civil del 02 de febrero de dos mil uno (2001) Ref: Expediente No. 5670 M.P. Carlos Ignacio Jaramilo 
Corte Constitucional, Sentencia T-222, M.P. Luis Ernesto Vargas Silva.

Corte Suprema de Justicia Sala de Casación Civil, Sentencia de 7 de mayo de 2002, Exp. 6181, M.P. José Fernando Ramirez Gomez.

Corte Suprema de Justicia, Sala de Casación Civil, Providencia de 29 de enero de 1998. Exp. 4894, M.P. Carlos Esteban Jaramillo Schloss.

Corte Suprema de Justicia, Sala de Casación Civil, Sentencia de 08 de agosto de 2007 Exp. 2000-00326, M.P. Cesar Julio Valencia Copete.

Corte Suprema de Justicia, Sala de Casación Civil, Sentencia de 14 de marzo de 2017, Rad. 2006-00131, M.P. Alvaro Fernando García.

Corte Suprema de Justicia, Sala de Casación Civil, Sentencia de 16 de diciembre de 2016, M.P. Alvaro García Restrepo.

Corte Suprema de Justicia, Sala de Casación Civil, Sentencia de 18 de diciembre de 2009, Exp. 2001-00389, M.P. Pedro Octavio Munar Cadena.

Corte Suprema de Justicia, Sala de Casación Civil, Sentencia de 1 de junio de 2007, M.P. Ruth Marina Diaz Rueda.

Corte Suprema de Justicia, Sala de Casación Civil, Sentencia de 16 de mayo de 2011. Expediente. 11001-3103-009-2000-09221-01, M.P. Ruth Marina Diaz Rueda.

Corte Suprema de Justicia, Sala de Casación Civil, Sentencia de 18 de octubre de 1995, M.P. M.P. Pedro Lafont Pianetta.

Corte Suprema de Justicia, Sala de Casación Civil, Sentencia de 19 de mayo de 1999, M.P. José Fernando Ramirez Gomez.

Corte Suprema de Justicia, Sala de Casación Civil, Sentencia de 19 de diciembre de 2013, M.P. Ariel Salazar Ramírez.

Corte Suprema de Justicia, Sala de Casación Civil, Sentencia de 11 de abril de 2002, M.P. Jorge Santos Ballesteros.

Corte Suprema de Justicia, Sala de Casación Civil, Sentencia de 1 de agosto de 2002.

Corte Suprema de Justicia, Sala de Casación Civil, Sentencia de 19 de diciembre de 2008, Exp. 00075, M.P. Arturo Solarte Rodriguez.

Corte Suprema de Justicia, Sala de Casación Civil, Sentencia de 14 de julio de 2006, M.P. Silvio Fernando Trejos Bueno.

Corte Suprema de Justicia, Sala de Casación Civil, Sentencia de 28 de julio de 2005, Exp. 1999-00449-01, M.P. Manuel Isidro Ardila Velásquez. 
Corte Suprema de Justicia, Sala de Casación Civil, Sentencia de 29 de septiembre de 2005, Expediente. 22940.

Corte Suprema de Justicia, Sala de Casación Civil, Sentencia de 25 de mayo de 2005, Exp. C-7198.

Corte Suprema de Justicia, Sala de Casación Civil, Sentencia de 29 de enero de 2015, Exp. STC 514-2015, M.P. Margarita Cabello Blanco.

Corte Suprema de Justicia, Sala de Casación Civil, Sentencia de 25 de julio de 2013, Exp. 11001-02-03-000-2013-01591-000.

Corte Suprema de Justicia, Sala de Casación Civil, Sentencia de 28 de julio de 1976, M.P. José María Esguerra Samper.

Corte Suprema de Justicia, Sala de Casación Civil, Sentencia de 21 de marzo de 1977, Exp. 2369.

Corte Suprema de Justicia, Sala de Casación Civil, Sentencia de 2 de agosto de 2001, M.P. Carlos Ignacio Jaramillo Jaramillo.

Corte Suprema de Justicia, Sala de Casación Civil, Sentencia de 23 de mayo de 1988, Exp.S-177.

Corte Suprema de Justicia, Sala de Casación Civil, Sentencia de 24 de octubre de 2005.

Corte Suprema de Justicia, Sala de Casación Civil, Sentencia de 21 de mayo de 2002, Exp. 7288.

Corte Suprema de Justicia, Sala de Casación Civil, Sentencia de 23 de marzo de 2004, Expediente 14576, M.P. Silvio Fernando Trejos.

Corte Suprema de Justicia, Sala de Casación Civil, Sentencia de 30 de noviembre de 2000, M.P. Jorge Castillo Rugeles.

Corte Suprema de Justicia, Sala de Casación Civil, Sentencia de 30 de junio de 2011, Exp. No. 76001-31-03-006-1999-00019-01, M.P. Edgardo Villamil Portilla.

Corte Suprema de Justicia, Sala de Casación Civil, Sentencia de 4 de noviembre de 2009. Exp. 4175, M.P. Pedro Octavio Munár Cadena.

Corte Suprema de Justicia, Sala de Casación Civil, Sentencia de 5 de octubre de 2009, Expediente. 03366.

Corte Suprema de Justicia, Sala de Casación Civil, Sentencia de 5 de julio de 2012, Exp. 2005-00425-01, M.P. Fernando Giraldo Gutierrez. 
Corte Suprema de Justicia, Sala de Casación Civil, Sentencia de 9 de septiembre de 1977, Exp. 2398, M.P. Aurelio Camacho Rueda.

Corte Suprema de Justicia, Sala de Casación Civil, Sentencia del 25 de mayo de 2005, Exp. No. C-7198, M.P. Arrubla Paucar, Jaime Alberto.

Corte Suprema de Justicia, Sala de Casación Civil, Sentencia del 15 de diciembre de 2008, Exp. No. C-1100131030352001-01021-01.

Deberes de información en la etapa pre-contractual a cargo del aseguros y candidato a tomador. Castro, Jose Fernando Torres Fernandez de. 2003. 19, s.1. : Universidad Javeriana, 2003, Revista Ibero-Latinoamericana de Seguros.

Díaz Granados, J.M. (2012). El nuevo estatuto del consumidor. Su incidencia en el contrato de seguro. Revista Iberolatinoamericana de Seguros, Vol. 21 No. 36.

El artículo 82 de la Ley 45 de 1990 reformatorio del artículo 1068 del Código de Comercio. Ordoñez, Andrés Ordoñez. 2011. 2011, Mercatoria.

El nuevo estatuto del consumidor. Su incidencia en el contrato de seguro. Manuel, Díaz-Granados Juan. 2012. 2012, Revista Ibero-Latinoamericana de Seguros, págs. 92-93.

El tratamiento civil de la mala fe del asegurado en el contrato de seguro. Ordóñez, Andres Ordóñez. 2005. 2, 2005, Revista Mercatoria, Vol. 4.

Falta de legitimación en el seguro de vida grupo deudores. Mejia Martinez, Carmenza. 2012. Bogotá : Publicaciones Universidad Externado de Colombia, 2012, ESCRITOS SOBRE RIESGOS Y SEGUROS, págs. 245-264.

Jaramillo, Carlos Ignacio Jaramillo. 2001. Corte Suprema de Justicia Sala de Casacion Civil. Sentencia de 14 de diciembre de 2001, Rad. 6230, s.1. : Corte Suprema de Justicia Sala de Casacion Civil, 14 de diciembre de 2001.

Jaramillo, Carlos Ignacion. 2015. Derecho de Seguros y Reaseguros. Bogotá : Grupo Editorial Ibañez, 2015.

Legitimación de la viuda y de los herederos bajo el seguro de vida grupo deudores. Narváez Bonnet, Jorge Eduardo. 2013. 2013, Revista Ibero Americana de Seguros, págs. 69-111.

Legitimación del cónyuge sobreviviente y de los herederos con ocasión de los contratos de seguros de vida grupo deudores. Ramírez Gómez, José Fernando. 2015. 2015, Revista Ibero Americana de Seguros, págs. 103-121.

Ordoñez, A. (2012). Estudios de Seguros. Bogotá: Universidad Externado de Colombia.

Ossa G, J. E. (1963). Tratado Elemental de Seguros. Bogotá: Ediciones Lerner. 
Superintendencia Financiera de Colombia, Concepto 2011013293-002 de 28 de abril de 2011.

Superintendencia Financiera de Colombia, Concepto de 09 de agosto de 2002.

Superintendencia Financiera de Colombia, Delegartura para Funciones Jurisdiccionales, Sentencia de 22 de junio de 2015, Rad. 2014-100015.

Superintendencia Financiera de Colombia, Delegatura para Funciones Jurisdiccionales, Sentencia de 12 de noviembre de 2014, Rad. 2014-0409.

Superintendencia Financiera de Colombia, Delegatura para Funciones Jurisdiccionales, Sentencia de 17 de julio de 2014, Rad. 2014-024951.

Superintendencia Financiera de Colombia, Delegatura para Funciones Jurisdiccionales, Sentencia de 10 de abril de 2014, Rad. 2013-0545.

Superintendencia Financiera de Colombia, Delegatura para Funciones Jurisdiccionales, Sentencia 21 de abril de 2014, Rad. 2013-0542.

Superintendencia Financiera de Colombia, Delegatura para Funciones Jurisdiccionales, Sentencia de 28 de enero de 2014, Rad. 2013-0345.

Superintendencia Financiera de Colombia, Delegatura para Funciones Jurisdiccionales, Sentencia de 14 de noviembre de 2014, Rad.2014-0221.

Superintendencia Financiera de Colombia, Delegatura para Funciones Jurisdiccionales, Sentencia de 27 de junio de 2013, Radicado 2012-0035.

Superintendencia Financiera de Colombia, Delegatura para Funciones Jurisdiccionales, Sentencia 9 de enero de 2015, Rad. 2014-0698.

Superintendencia Financiera de Colombia, Delegatura para Funciones Jurisdiccionales, Sentencia de 30 de abril de 2014, Rad. 2013-0662.

Superintendencia Financiera de Colombia, Delegatura para Funciones Jurisdiccionales, Sentencia de 24 de enero de 2014, Rad.2013-0333.

Superintendencia Financiera de Colombia, Delegatura para Funciones Jurisdiccionales, Sentencia 11 de junio de 2014, Rad. 2013-0800.

Superintendencia Financiera de Colombia, Delegatura para Funciones Jurisdiccionales, Sentencia de 17 de enero de 2014, Rad. 2013-0372.

Superintendencia Financiera de Colombia, Delegatura para Funciones Jurisdiccionales, Sentencia 16 de febrero de 2016, Rad. 2015-1148. 
Superintendencia Financiera de Colombia, Delegatura para Funciones Jurisdiccionales, Sentencia de 26 de septiembre de 2014, Rad. 2014-0082.

Superintendencia Financiera de Colombia, Delegatura para Funciones Jurisdiccionales,

Sentencia de 26 de noviembre de 2014, Rad. 2014-0419.

Superintendencia Financiera de Colombia, Delegatura para Funciones Jurisdiccionales, Sentencia de 29 de enero de 2015, Rad. 2014-0634.

Superintendencia Financiera de Colombia, Delegatura para Funciones Jurisdiccionales, Sentencia de 15 de febrero de 2016, Rad. 2015-0819.

Superintendencia Financiera de Colombia, Delegatura para Funciones Jurisdiccionales, Sentencia de 9 de abril de 2015, Rad 2015-0725.

Superintendencia Financiera de Colombia, Delegatura para Funciones Jurisdiccionales, Sentencia de 28 de abril de 2015. Rad.2015-0963.

Superintendencia Financiera de Colombia, Delegatura para Funciones Jurisdiccionales, Sentencia de 12 de febrero de 2016, Rad. 2015-1299.

Superintendencia Financiera de Colombia, Delegatura para Funciones Jurisdiccionales, Sentencia de 13 de diciembre de 2013, Rad. 2013-0076.

Superintendencia Financiera de Colombia, Delegatura para Funciones Jurisdiccionales, Sentencia de 3 de marzo de 2015, Rad. 2014-0675.

Superintendencia Financiera de Colombia, Delegatura para Funciones Jurisdiccionales, Sentencia de 8 de Mayo de 2014, Rad. 2013-0686.

Superintendencia Financiera de Colombia, Delegatura para Funciones Jurisdiccionales, Sentencia de 13 de noviembre de 2013.

Superintendencia Financiera de Colombia, Delegatura para Funciones Jurisdiccionales, Sentencia de 17 de enero de 2014, Rad. 2013-0372-155.

Superintendencia Financiera de Colombia, Delegatura para Funciones Jurisdiccionales, Sentencia de 17 de enero de 2014, Rad. 2013-0372-155.

Superintendencia Financiera de Colombia, Delegatura para Funciones Jurisdiccionales, Sentencia de 29 de junio de 2016, Rad.2015-2221. 